\title{
Examining Factors Influencing Jordanian Customers' Intentions and Adoption of Internet Banking: Extending UTAUT2 with Risk
}

\author{
Ali Abdallah Alalwan \\ Amman College of Banking and Financial Sciences \\ Al-Balqa' Applied University, Amman, Jordan \\ alwan.a.a.ali@gmail.com \\ Yogesh K. Dwivedi \\ School of Management \\ Swansea University \\ Bay campus, Fabian Way \\ Swansea, SA1 8EN, UK \\ y.k.dwivedi@swansea.ac.uk \\ Nripendra P. Rana* \\ School of Management \\ Swansea University \\ Bay Campus, Fabian Way \\ Swansea, SA1 8EN, UK \\ Tel: +44(0) 1792295179 \\ nrananp@gmail.com \\ Raed Algharabat \\ The School of Business Department of Marketing, \\ The University of Jordan, Amman, Jordan \\ r.gharabat@ju.edu.jo
}

\begin{abstract}
The key objective of this study is to propose and examine a conceptual model that best explains the key factors influencing Jordanian customers' intentions and adoption of Internet banking. The conceptual model proposed was based on the extended Unified Theory of Acceptance and Use of Technology (UTAUT2). This was further extended by adding perceived risk as an external factor. Structural equation modelling (SEM) was conducted to analyse the data collected from the field survey questionnaires administered to a convenience sample of Jordanian banking customers. The results show that behavioural intention is significantly influenced by performance expectancy, effort expectancy, hedonic motivation, price value and perceived risk; however, social influence does not have a significant impact on behavioural intention. This study offers Jordanian banks some guidelines for designing and marketing such channel in order to enhance their acceptance by their customers.
\end{abstract}

Keywords: Internet banking, Adoption, Jordan, Customer, UTAUT2, Risk 


\section{Introduction}

Given the intensity of the competition, increasing the customers' sensitivity to issues related to cost, time and convenience, banks have begun to make use of technological applications in their endeavours to override the restrictions pertaining to human encounter (Al-Hawari et al., 2009; Baptista and Oliveira, 2015; Boateng et al., 2016; Ho and Ko, 2008; Lin and Hsieh. 2011; Orel and Kara, 2014). Indeed, technological breakthroughs have dramatically contributed to the nature of the business environment by introducing new mechanisms that can enhance a bank's capability to provide customers with a high quality service and greater convenience (Al-Hawari et al., 2009; Yoon and Steege, 2013; Zhu et al., 2013). One of these breakthroughs is Internet banking (IB), which offers an innovative way of providing customers with a wide range of financial services, whilst replacing the role of a human encounter (Akhlaq and Ahmed, 2013; Curran and Meuter, 2005, 2007; Martins et al., 2014; Riffai et al., 2012). Shih and Fang (2004) defined IB as banking applications that allow customers to access and conduct their financial transactions (i.e. balance enquiries, fund transfers, paying bills, stock market) using the World Wide Web, Wi-Fi technologies and the Internet, at a time and place of the user's choosing.

By utilising Internet banking channels, banks also endeavour to minimise the labour and operational costs that pertain to traditional encounters (Bitner et al., 2002; Hung et al., 2012; Lin and Hsieh, 2011). For instance, the cost of a transaction conducted via Internet banking is about US $\$ 0.01$, compared with US $\$ 1.07$ for those conducted by traditional methods (Cuevas, 1998; DeYoung et al., 2007; Hall et al., 1999; Kolodinsky et al., 2004; Lee, 2009; Xue et al., 2011).

The successful implementation of IB requires a level of customer acceptance of such system that justifies the banks' investments in this respect (Akhlaq and Ahmed, 2013; Celik, 2008; Curran and Meuter, 2007). In fact, despite large amounts of effort and money being invested, the adoption of IB in Jordan is not in line with what was expected, and Jordanian banking customers are still slow in accepting these technologies (Al-Rfou, 2013). Along the same lines, based on a recent survey including 40 specialist bank staff involved in online transaction departments in Jordanian commercial banks, Al-Rfou (2013) provided statistics demonstrating a low usage rate of IB in Jordan. Al-Rfou (2013) illustrated that less than 19\% of Jordanian banking customers have accessed online banking services, while less than $21 \%$ of customers are actually able to use IB in Jordan. A lack of awareness of the existence of IB was reported by $61 \%$ of the employees surveyed as the main barrier to using this technology 
in Jordan (Al-Rfou, 2013). Indeed, this problem has been noticed in different countries especially across the developing countries (Sharma et al., 2017). For instance, a recent report carried out by ComScore (2012) also indicated that out of four Internet users, there was only one who accessed Internet banking website worldwide. ComScore's (2012) report stated that the number of individuals logging on to online banking websites in April 2012 was about 424.5 million $(28.7 \%)$ of the total Internet users around the world. The same ComScore report (2012) also illustrated that the highest penetration rate of online banking websites was in North America (45\%) followed by Europe (37.8\%) and then Latin America $(25.1 \%)$ whereas the lowest rate was found in the Middle East and Africa (8.8\%).

The statistics provided above indicate the low usage rate of Internet banking services by Jordanian customers. Hence, Jordanian banks have begun to express concern regarding the low adoption rate of innovative channels, as well as questioning the feasibility of introducing these channels, especially given the large amount of resources being invested in it (Alalwan et al., 2015; AbuShanab et al., 2010; Al-Majali, 2011; Al-Rfou, 2013; Al-Smadi, 2012; Al Sukkar and Hasan, 2005). This, in turn, has led to the perception of Internet banking as a double-edged sword (Chiu et al., 2010; Hilton et al., 2013; Hung et al., 2012; Meuter et al., 2005). Indeed, customer reluctance to use this technology means that it is pointless to invest in Internet banking channels, while banks find themselves having to continue to provide their services via human encounters, along with their associated operational and labour costs (Chiu et al., 2010; Hilton et al., 2013; Hung et al., 2012; Lee and Allaway, 2002).

In the light of these facts, the main challenge for the success of Internet banking not only depends on providing these emerging applications but rather attracting customers to accept them as a full alternative instead of a human encounter. In this regard, Meuter et al. (2005, p.78) stressed that "for many firms, often the challenge is not managing the technology but rather getting consumers to try the technology." In effect, persuading customers to switch their behaviour from traditional encounters to using Internet banking channels is not an easy process, especially as there is a lack of understanding of this phenomenon from the customers' perspective (Curran and Meuter, 2007). Thus, there is a need to understand and study the factors that hinder or contribute to the customers' intentions and behaviours toward such technology.

As motivating customers to switch their behaviour from traditional human encounters to using IB channels is not an easy process, there is always a need to identify and empirically examine the main predictors that could shape the customers' intention and adoption of IB in 
Jordan. Nevertheless, a few researchers (e.g. Alalwan et al., 2015; AbuShanab et al., 2010) have empirically examined the Jordanian customers' intention and adoption of IB. Thus, this study realises a need to examine the factors that hinder or contribute to the Jordanian customers' intentions and behaviours toward IB. Further, the results of current study could provide more clues about the perception and behaviours of customer over the Middle East and developing countries in general. So that the generalizability of the current study's results will not only be restricted by the Jordanian markets but also could be of interest to practitioners and academics in the Middle East and Arab countries. This is especially important due to the fact that most prior studies of Internet banking have examined the related issues from the perspectives of customers in developed countries.

Accordingly, this study attempts to address these main research questions:

1. What is the current state of Jordanian customers' intention and adoption of Internet banking?

2. What are the main factors that could hinder or contribute to the Jordanian customers' intention and adoption of Internet banking?

3. What Jordanian banks could do to enhance the customers' level of adoption of Internet banking?

\section{Literature Review}

The body of IB literature is large where numerous factors have been examined and many theories were formulated (Hung et al., 2012; Martins et al., 2014; Orel and Kara, 2014; Tam and Oliveira, 2016; Zhu et al., 2013). Yet, examination of the acceptance of IB has received the most considerable interest over the past few years (e.g. Eriksson and Nilsson, 2007; Eriksson et al., 2005; Jaruwachirathanakul and Fink, 2005; Tan and Teo, 2000).

Several factors have been examined and verified as key determinants of customer intention and usage of Internet banking. For instance, based on data obtained from 249 banking customers in Portugal, Martins et al. (2014) found performance expectancy, effort expectancy, and social influence as significant factors influencing customers' intention to adopt Internet banking. Moreover, Shih and Fang (2004) reported that the actual usage of Internet banking was strongly associated with behavioural intention. In Oman, Riffai et al. (2012) revealed that performance expectancy, effort expectancy, playfulness, and website design were proved to be significant contributors to the customers' intention. Walker and Johnson (2006) articulated that a customer's predisposition to adopt three kinds of SST - 
Internet banking, telephone bill payment, and online shopping - was significantly predicted by the customer's beliefs regarding their ability and capacity to apply the technological interfaces effectively. These findings have been supported by Al-Somali et al. (2009) in Saudi Arabia, who asserted that perceived ease of use enjoys a considerable role in promoting both perceived usefulness and customer attitudes toward Internet banking.

Eriksson et al. (2005) maintained perceived usefulness as a key factor that fully mediated the impact of perceived ease of use and trust on customers' use of Internet banking by Estonian clients. Later, in context of Estonia, Eriksson and Nilsson (2007) supported the role of perceived usefulness in enhancing both customers' willingness to continue using Internet banking and multichannel customer satisfaction. Similarly, perceived ease of use and perceived usefulness have been approved by Chiou and Shen (2012) as key factors predicting customers' attitudes toward Internet banking usage, and ultimately, facilitating the customers' willingness to accept this technology to obtain banking transactions. In addition, customers who perceive Internet banking as easy are more likely to value this technology as a useful commodity in their daily life. This is supported by both Chiou and Shen (2012) and Dimitriadis and Kyrezis (2011). In India, Kesharwani and Bisht (2012) predicted that perceived ease of use was recognised as a significant driver of perceived usefulness, and accordingly enhanced the customers' intention to adopt Internet banking.

In Germany, Berger (2009) verified a strong positive correlation between both perceived usefulness and ease of use with customer attitude toward self-service banking channels. Berger (2009) found attitude as a key determinant of the customers' willingness to adopt Internet banking. According to Curran and Meuter (2005), both perceived ease of use and perceived usefulness were able to explain a significant variance in the customers' attitude toward online banking, while customers' attitude was found as a key enabler of the customers' penchant to use online banking. In their efforts to examine the impact of customer perceived value and intention related to Internet banking, Ho and Ko (2008) strongly argued that perceived ease of use, perceived usefulness, cost savings, and self-control are crucial factors determining both customer readiness, customer value and ultimately customers' intention to continue to use Internet banking.

Akhlaq and Ahmed (2013) have applied SEM to analyse data collected from 109 banking customers in Pakistan in order to examine the impact of intrinsic and extrinsic motivations on both trust and usage of Internet banking. Their statistical results strongly support the impact of intrinsic motivation on customer trust which, in turn, positively enhances customer 
inclination to adopt Internet banking. However, based on measurement results, Akhlaq and Ahmed, (2013) reported that extrinsic motivation was not valid and therefore the conceptual model was applicable only to intrinsic motivation. Likewise, Celik (2008) provided empirical evidence to show that intrinsic motivation (playfulness) plays a strong positive role in predicting both perceived usefulness and perceived ease of use. Celik (2008) further empirically demonstrated that perceived usefulness and attitude play critical role in shaping customer intention to adopt Internet banking in Turkey. Curran and Meuter (2007) also indicted that the expected outcomes of using online banking, like utility and enjoyment, were found to contribute to customer willingness to change behaviour and adopt online banking.

Internet banking characteristics (e.g. compatibility, complexity, trialability and convenience) have been commonly recognised as key drivers in explaining a considerable variance in customer intention and acceptance of Internet banking (Black et al., 2001; Black et al., 2002; Gan et al., 2006; Gerrard and Cunningham, 2003; Kolodinsky et al., 2004; Liao et al., 1999; Shih and Fang, 2004; Tan and Teo, 2000). A number of studies have paid attention to the role of social factors on customers' intention to adopt Internet banking (Gerrard and Cunningham, 2003; Howcroft et al., 2002; Jaruwachirathanakul and Fink, 2005; Riffai et al., 2012; Shih and Fang, 2004).

As for the influence of personality and demographic factors, Nilsson (2007) indicated that users of Internet banking in Estonia seem to be more homogenous due to the fact that most of them are well-educated, younger, and more male than female. Moreover, Yoon (2010) predicted that customers who enjoy an adequate level of experience with technology are more likely to be pleased about Internet banking services if they perceived that Internet banking had fewer complexes, better design and more speed. In the same study, Yoon (2010) indicated that customer support services, along with sufficient and accurate information facilitating the using of Internet banking, were positive predictors of satisfaction. In their examination of the impact of demographic factors on customer attitude toward Internet banking in Saudi Arabia, Al-Somali et al. (2009) found that an education level was a significant predictor in this respect. Jaruwachirathanakul and Fink (2005) concluded that the causal association between perceived behavioural control and the adoption of Internet banking is not moderated by gender and age differences.

Issues related to perceived risk include the key barriers to customers' willingness to use and accept Internet banking (Al-Gahtani, 2011; Black et al., 2001; Celik, 2008; Chiou and Shen 2012; Cunningham et al., 2009; Curran and Meuter, 2007; Eriksson et al., 2005; Gan, et al., 
2006; Gerrard et al., 2006; Jaruwachirathanakul and Fink, 2005; Kesharwani and Bisht, 2012; Kolodinsky, et al., 2004; Lee, 2009; Littler and Melanthiou, 2006; Aldás-Manzano et al., 2009; Martins et al., 2014; Ndubisi and Sinti, 2006; Nor and Pearson, 2008). According to Kesharwani and Bisht (2012), Tan (1999) and Martin and Camarero (2008), associated risks have been addressed largely with regard to self-service banking channels rather than those associated with a human encounter. This could be attributed to the absence of physical interaction between customers and service providers in the case of online transactions; furthermore, the outcomes of using these technologies are generally characterised by uncertainty and ambiguity (Al-Gahtani, 2011). In line with this, Yousafzai et al. (2009) also argued that loss of confidence plays a negative role, not only in the banking context, but also with regard to other e-commerce applications. According to Martins et al. (2014), perceived risk was found to be a key obstacle to the customers' willingness to adopt Internet banking.

As mentioned before, there are only a few studies examining the adoption of IB in Jordan (i.e. AbuShanab et al., 2010; Al-Majali, 2011; Al-Smadi, 2012). The findings of these studies have contributed to the overall understanding of the critical factors relating to the adoption of IB in Jordan. However, despite the importance of intrinsic motivation and habit as critical predictors for the adoption of IB (Lin and Hsieh, 2011; Venkatesh et al., 2012), the factors such as intrinsic motivation and habit have not received any attention in prior studies of IB in Jordan. Perceived value is also not fully explained by the studies conducted in the Jordanian context. This demonstrates a need to clarify aspects relating to the value of using IB such as price value; in particular, these aspects could play a vital role in shaping customer intention and behaviour toward IB (Venkatesh et al., 2012). Furthermore, the impacting role of intrinsic motivation on both price value and perceived usefulness is worth examining Moreover, such relationships between the functional utilities (i.e. perceived usefulness, performance expectancy) and customer perceived value (i.e. price value) of IB represent a worthwhile research direction to be tested and explained.

\section{Conceptual Model}

As extending the UTAUT2 is precisely theorised to explain technology acceptance from the customers' perspective (Venkatesh et al., 2012), it was selected as an appropriate theoretical foundation to propose the conceptual model, which has been utilised in this study. From a review of relevant literature in information systems and marketing, three salient constructs - hedonic motivation, price value and habit - are identified and modelled in 
UTAUT2 along with performance expectancy, effort expectancy, social influence, and facilitating conditions (Venkatesh et al., 2012). By having these constructs (i.e. hedonic motivation, price value and habit) in the UTAUT2, new mechanisms such as intrinsic motivation, financial limitations and automaticity have been attached to the model (Venkatesh et al., 2012). Further, perceived risk was found to be conceptually and operationally different from the main constructs in UTAUT2.

As shown in Figure 1, the main constructs in UTAUT2 namely, performance expectancy (PE), effort expectancy (EE), social influence (SI), hedonic motivation (HM) and price value (PV) were proposed as direct determinants of customers' intention to use IB. The hypotheses development and justification for the main constructs will be discussed in depth in the following subsections.

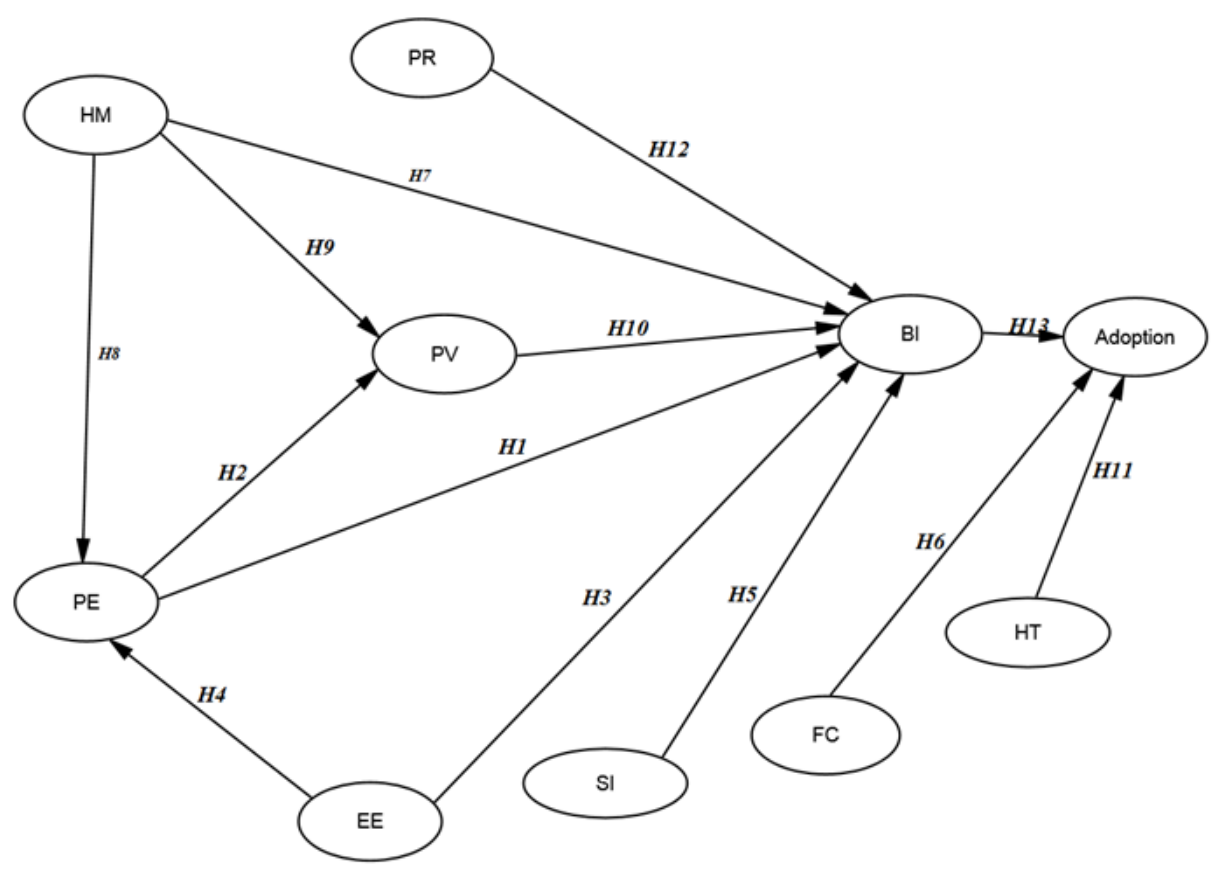

Figure 1: Proposed Conceptual Model (Featherman and Pavlou, 2003; Venkatesh et al., 2012)

\subsection{Performance Expectancy (PE)}

Performance expectancy can be conceptualised as the benefits and utilities (e.g. saving time and effort, efficiency, accessibility, customisation, convenience) that could be attained from using such innovative channel (Venkatesh et al., 2003). Performance expectancy has been noticed as one of the most influential drivers of behavioural intention to adopt and use information systems (IS)/information technology (IT) (e.g. Dwivedi et al., 2017a, 2017b, Rana et al., 2015, 2016, 2017) in general and IB (Alalwan et al., 2017; AbuShanab et al., 2010; Riffai et al., 2012; Martins et al., 2014) in particular. Importantly, Venkatesh et al. 
(2012) and Dodds et al. (1991) argued that customers usually are involved in a rational comparison process between the extent of benefits and utilities obtained by using technology in relation to the monetary cost paid to use technology from another point of view. Thus, further benefits and utilities perceived by using IB could contribute to the price value of IB (Alalwan et al., 2016b; Sheth et al., 1991; Tarhini et al., 2016; Zhu et al., 2013). This assumption was strengthened by Ho and Ko (2008) who empirically proved that customer value of self-service banking technology is positively associated with perceived usefulness. Therefore, this study articulates the following hypotheses:

H1: Performance expectancy will increase Jordanian customers' intention to adopt IB.

H2: Performance expectancy will increase price value related to using IB.

\subsection{Effort Expectancy (EE)}

Effort expectancy is conceptualised as the "extent of ease connected with the use of system" (Venkatesh et al., 2003, p.450). Several IB studies have empirically proven the important role of effort expectancy (i.e. Martins et al., 2014; Riffai et al., 2012) or it's captured factors such as perceived ease of use (i.e. Alalwan et al., 2016c; Al-Somali et al., 2009; Kesharwani and Bisht, 2012; Rodrigues et al., 2016; Wang et al., 2003) in shaping the customers' intention and perception toward such innovative channel. In keeping with the argument of Davis et al. (1989), individuals could be involved in the cognitive trade-off process between the efforts required to successfully apply the technology in front of the benefits and advantages attained by using technology. Therefore, Davis et al. (1989) articulated that perceived ease of use could contribute to the behavioural intention to use technology directly or indirectly by facilitating the role of perceived usefulness. This has been empirically supported at the context of IB by a number of studies (e.g. Al-Somali et al., 2009; Cheng et al., 2006a; Celik, 2008; Eriksson et al., 2005; Kesharwani and Bisht, 2012). Thus, this study formulates the following hypotheses:

H3: Effort expectancy will increase Jordanian customers' intention to adopt IB.

H4: Effort expectancy will increase performance expectancy of IB. 


\subsection{Social Influence (SI)}

Social influence was defined by Venkatesh et al. (2003, p.450) as "the extent to which an individual perceives that important others believe he or she should apply the new system". Venkatesh et al. (2003) debated that the impact of social influence on the behavioural intention could be due to compliance particularly in the initial stages of experience. The considerable role of social influence or their similar factors (i.e. reference groups, subjective norms and opinion leaders) in enhancing customer intentions and the use of IB has been broadly highlighted in prior studies (Al-Somali et al., 2009; AbuShanab et al., 2010; Martins et al., 2014; Shih and Fang, 2004). Therefore, the following hypothesis can be formulated based on above discussion:

H5: Social influence will increase Jordanian customers' intention to adopt IB.

\subsection{Facilitating Conditions (FC)}

Facilitating conditions are defined as "the degree to which an individual believes that an organizational and technical infrastructure exists to support use of the system" (Venkatesh et al., 2003, p.453). Upon closer review of the previous studies in the IS area, Venkatesh et al. (2003) articulated that the impact of facilitating conditions on the behavioural intention would not be significant if effort expectancy as well as performance expectancy constructs are included. Thus, the current study will follow the proposition of Venkatesh et al. (2003) by drawing only single path from facilitating conditions to the actual adoption of IB. Such

relationship between facilitating conditions and actual usage behaviour has been empirically proven by different studies (i.e. Alalwan et al., 2016a; Zhou et al., 2010; Wang and Shih, 2009) over the relevant areas of research.

Indeed, Venkatesh et al. (2012) supposed that the facilitating conditions could have direct influence on the customers' intention in UTAUT2 as facilitating conditions are not freely available for the customers as in the case of the employee context. However, the vast majority of Jordanian banks provide these facilities free of charge or with a cheaper price (e.g. Bank of Jordan, 2014; Housing Bank, 2014; Jordan Ahli Bank, 2014; Standard Chartered Jordan, 2014). Further, according to Venkatesh et al. (2003), the impacting role of facilitating conditions on behavioural intention is more likely to vanish by including both performance expectancy and effort expectancy as key predictors of behavioural intention. Therefore, in this study, facilitating conditions were proposed to have only one direct influence on the actual usage behaviour. Hence, the following hypothesis can be formulated: 
H6: Facilitating conditions will increase adoption of IB by Jordanian customers.

\subsection{Hedonic Motivation (HM)}

According to Venkatesh et al. (2012), hedonic motivation is conceptualised as the feeling of cheerfulness, joy or enjoyment, which is stimulated by applying technology. More thorough analysis of relevant literature in customer behaviour as well as technology acceptance streams, Venkatesh et al. (2012) revealed that several factors such as playfulness, joy, and enjoyment capture the hedonic motivation and are significant determinants of customer acceptance of technology (Brown and Venkatesh, 2005; Childers et al., 2001; Van der Heijden 2004). Interestingly, using online banking channels could be perceived as being part of a modern lifestyle, adding further value to the segment of customers who look for novelty and modernism (Celik, 2008; Gan et al., 2006; Lin and Hsieh, 2011; Riffai et al., 2012). The important role of intrinsic motivation in shaping customers' intention to adopt IB has been supported by different studies of IB (i.e. Curran and Meuter, 2007; Gan et al., 2006). In addition to customers who perceive using the technology that comprises of fun, playfulness, and enjoyment, they are more than likely to perceive using this technology in a more productive manner requiring less effort, and hence, will contribute to value perceived by using such a system (e.g. performance expectancy, price value) (Cheng et al., 2006; Moon and Kim, 2001; Venkatesh, 2000). Indeed, Agarwal and Karahanna (2000) empirically confirmed the role of cognitive absorption (as an intrinsic variable) in enhancing the perceived usefulness. Therefore, if hedonic motivation of using IB is high, the overall benefits perceived by using this technology will increase, and accordingly, that will contribute to both the performance expectancy and the price value of using IB as well (Dodds et al., 1991; Venkatesh et al., 2012). Therefore, the following hypotheses can be formulated:

\footnotetext{
H7: Hedonic motivation will increase Jordanian customers' intention to adopt IB.
}

H8: Hedonic motivation will increase the performance expectancy of using Internet banking.

H9: Hedonic motivation will increase the price value of using IB. 


\subsection{Price Value (PV)}

Price value is conceptualised as "consumer's cognitive trade-off between the perceived benefits of the application and the monetary cost for using it" (Venkatesh et al., 2012, p.161). Instead of the employee context where the cost concept could be represented in terms of time and effort, which are theorised under the effort expectancy, financial cost represents a crucial role in shaping customers' willingness to adopt and accept new technology (Mallat et al., 2008; Venkatesh et al., 2012). Additionally, based on the marketing literature, perceived value is usually identified by how the customer cognitively compares how much he/she should pay instead of utilities and quality attained (Dodds et al., 1991). Therefore, if the utilities, which a customer can attain by adopting a high-tech product, are higher than the financial cost, the price value will positively predict the customers' intention to use the technology (Venkatesh et al., 2012). Theoretically, there are different studies over the relevant areas that have addressed the impact of the perceived value and price value on the customer's intention to use electronic channels (Al-Hawari and Ward, 2006; Ding et al., 2007; Gerrard and Cunningham, 2006; Ho and Ko, 2008; Lee and Allaway, 2002; Sathye, 1999). Thus, the following hypothesis postulates:

H10: Price value will increase Jordanian customers' intention to adopt IB.

\subsection{Habit $(H B)$}

Venkatesh et al. (2012, p.161) defined habit as "the extent to which people tend to perform behaviour automatically because of learning." Also, Venkatesh et al. (2012) argued that while behavioural intention has been identified as the most significant factor predicting technology adoption, habit, according to Davis and Venkatesh (2004), has been recognised as an alternative determinant to technology usage. Habit, as previously mentioned, is related to automaticity behaviour, which is formed by an accumulation of knowledge and skills over time (Limayem et al. 2007; Venkatesh et al., 2012). Although habit has been ascertained by several studies of IB, the majority of these studies have discussed the negative impact of habitual behaviour related with traditional banking channels on the customers' tendency to adopt the electronic channels (i.e. Laukkanen et al., 2008; Kuisma et al., 2007; Wan et al. 2004). On the other hand, Kolodinsky et al. (2004) and Eriksson et al. (2008) empirically demonstrated that the extent of compatibility of online banking with the customers' habits is a significant predictor of the customers' adoption of online banking in the USA. In the current study, it was followed the proposition of the UTAUT2, which assumes a positive role 
for habit in motivating the adoption behaviour of Internet banking. Thus, the following hypothesis postulates that:

H11: Habit will increase adoption of IB by Jordanian banking customers.

\subsection{Perceived Risk (PR)}

Perceived risk could be defined as the likelihood of a customer suffering a loss in pursuit of the favoured consequences of applying IB (Featherman and Pavlou, 2003). Several studies have paid particular attention to issues that are concerned with perceived risk (Curran and Meuter, 2005; Flavián et al., 2006). Indeed, aspects related to perceived risk have been widely regarded as crucial negative determinants of customers' intentions and the adoption of IB (Baabdullah et al., 2016; Gan et al., 2006; Gerrard et al., 2006; Laukkanen et al., 2008; Poon, 2008; Flavián et al., 2006). The particular interest in these factors could be attributed to the high uncertainty, intangibility, heterogeneity and vagueness characterised in the online banking area, along with the absence of human interaction (Al-Gahtani, 2011; Curran and Meuter, 2005; Featherman and Pavlou, 2003; Kesharwani and Bisht, 2012; Martins et al.2014). Accordingly this study assumes the following hypothesis:

\section{H12: Perceived risk will decrease the Jordanian customers' intention to adopt Internet banking.}

\subsection{Behavioural Intention (BI)}

According to Venkatesh et al. (2003, 2012), behavioural intention is conceptualised as the extent to which the customer tends to use the self-service technology (SST). Behavioural intention has been examined constantly and confirmed as the most powerful determinant of individual behaviour over the technology acceptance stream (Ajzen, 1991; Venkatesh et al., 2003, 2012). Furthermore, prior literature in the SST has strongly supported customer intention as a decisive driver of the actual usage behaviour of SST (e.g. Jaruwachirathanakul and Fink, 2005; Martins et al., 2014; Shih and Fang, 2004; Wang and Shih, 2009). Therefore, this study conceptualises that behavioural intention is a decisive construct between the main antecedent constructs and customer usage of SST. Accordingly, this study formulates the following hypothesis:

\section{H13: Behavioural intention will increase adoption of IB by Jordanian banking customer.}




\section{Methodology}

In line with the aim of the current study which focuses on examining the factors impacting the Jordanian customers' intention and adoption of IB, sampling frame of the current study comprised of all Jordanian banking customers (potential users and actual users of IB) residing in two main cities in Jordan: Amman (the capital of Jordan) and Al-Balqa. Indeed, 500 selfadministered questionnaires were distributed to obtain the required data; yet, three hundred forty eight (70\% response rate) questionnaires were returned and found to be valid for further analyses. Practically, the convenience sample of Jordanian banking customers was reached by number of the following approaches:

- By direct contact with the targeted respondents at the bank branches

- By passing and returning the questionnaire to the respondents via the banking staff

- By approaching the banking customers in their own workplaces such as staff, Master's degree and Bachelor's degree students in a number of the universities and educational institutes, employees in the public or private sector and personnel in different institutions.

As discussed before, the self-administered questionnaire has been adopted in the current study to derive responses from Jordanian banking customers regarding their perception of the aspects related to behavioural intention and adoption of Internet banking. The same scale items used by Venkatesh et al. (2012) to measure UTAUT2: PE, EE, SI, FC, HM, PV, HT and BI) were also used to measure these constructs in the current study. Noteworthy, items of performance expectancy, effort expectancy, social influence, facilitating conditions, and behavioural intention were originally proposed by Venkatesh et al. (2003) in validating the original version of UTAUT. In line with UTAUT2, the current study also used the same set of items used by Venkatesh et al. (2012) to measure hedonic motivation, price value and habit. Such items related to UTAUT2 constructs have been extensively adapted and validated by prior IS/IT studies that have formulated this theory as a theoretical foundation in their conceptual models (AbuShanab et al., 2010; Chiu et al., 2010; Martins et al., 2014; Riffai et al., 2012; Wang and Shih, 2009; Zhou et al., 2010). As for perceived risk, seven items were adopted from Featherman and Pavlou (2003) to measure such construct. The Featherman and Pavlou's (2003) scale covers the main dimensions of perceived risk (i.e. performance risk, financial risk, privacy risk, and social risk). This scale has also been adapted by several studies examining the customer's intention and behaviour towards toward Internet banking (i.e. Al-Smadi, 2012; Celik, 2008; Martins et al., 2014). The seven-point Likert scale was 
used to measure the main items of the UTAUT2 constructs and perceived risk with anchors ranging from strongly agree to strongly disagree. Actual adoption of Internet banking was measured by a set of five common financial transactions that could be applied using IB. Indeed, these services have been widely adopted by relevant studies that have examined customers use or adoption of Internet banking (i.e. Curran and Meuter 2005/2007, Liao et al., 1999; Martins et al., 2014). In addition to this, these services have been approved by number of the most well-known Jordanian banks that have introduced such services (i.e. Bank of Jordan, Housing Bank, Arab Bank, Kuwait Bank, Jordan Islamic Bank, and Cairo Amman Bank). The seven-point time scale was adopted to measure the use behaviour toward these services with anchors including: never, once a year, several times a year, once a month, several times a month, several times a week, several times a day (Venkatesh et al., 2012). Demographic variables: age, gender, income, education level, Internet experience, and computer experience were measured using six close-ended questions.

Arabic is the native language of the respondents being targeted in the current study (Jordanian banking customers). The questionnaire, therefore, was converted to the Arabic language using the back translation method (Brislin, 1976). So as to validate the questionnaire prior the main survey, researchers conducted a pilot study via allocating 30 questionnaires to Jordanian banking customers. Those customers are requested to see the questionnaire given and freely presenting their feedback about any problems and confusions that could exist the questionnaire. Out of 30 questionnaires allocated, only 23 that have been returned. The vast majority of those respondents assured the suitability and clarity of the language used. As well as, the questionnaire is not long and does not consume too much time in filling it.

Furthermore, so as to assure adequate level of internal consistency reliability for all items used, a Cronbach's alpha test was applied using SPSS with cut off value of 0.70. In order to make sure that all measurement items have an acceptable level of internal consistency reliability, an examination of Cronbach's alpha values was carried out for the three questionnaires that were distributed using SPSS (Nunnally, 1978). All constructs were able to have a value higher than 0.70 . The largest value was noticed regarding performance expectancy (0.97) followed by price value (0.96) and then hedonic motivation (0.95). Effort expectancy and facilitating conditions have the same value of 0.89 . Perceived risk also has an acceptable value of 0.87 . Other acceptable values were accounted by social influence (0.85); habit (0.83); behavioural intention (0.81). The lowest Cronbach's alpha was found for 
adoption with value of (0.78). Accordingly, all constructs items used have adequate level of internal consistency and adequately satisfied the reliability criteria.

\section{Results}

\subsection{Respondents' Profile and Characteristics}

348 usable responses have been received. Noticeably, more than half of the respondents $(57.2 \%)$ were male, whereas females captured about $42.8 \%$ of the total sample. The descriptive statistics revealed that most of the respondents were found within the age group of $31-40(37.4 \%)$ and the age group of $25-30(32.2 \%)$. In the term of monthly income level (Jordanian Dinar (JOD)), the monthly income level of the largest segment of the usable sample $(28.8 \%)$ was between 400-600 JOD followed by those who had a monthly income less than 400 JOD (20.4\%). The most prominent educational level of respondents $(69.6 \%)$ had gained a Bachelor's Degree. The overwhelming majority of respondents (92.2\%) were computer users for more than three years. As for Internet experience, they are similar to the computer experience statistics. The vast majority of usable respondents (87.6\%) had experienced more than three years with the Internet.

Table 1: Demographic Characteristics of Internet Banking Respondents

\begin{tabular}{|c|c|c|c|c|c|}
\hline Category & Count & $\%$ & Category & Count & $\%$ \\
\hline \multicolumn{3}{|l|}{ Gender } & \multicolumn{3}{|c|}{ Education Level } \\
\hline Male & 199 & 57.2 & High school & 13 & 3.7 \\
\hline Female & 149 & 42.8 & Diploma & 37 & 10.6 \\
\hline Total & 348 & 100 & Bachelor & 242 & 69.6 \\
\hline \multicolumn{3}{|l|}{ Age (in Years) } & Master & 52 & 14.9 \\
\hline $18-24$ & 58 & 16.7 & $\mathrm{PhD}$ & 3 & 0.9 \\
\hline $25-30$ & 112 & 32.2 & Other & 1 & 0.3 \\
\hline $31-40$ & 130 & 37.4 & Total & 348 & 100 \\
\hline $41-50$ & 37 & 10.6 & \multicolumn{3}{|c|}{ Computer Experience } \\
\hline $51-60$ & 7 & 2 & $<$ One year & 6 & 1.7 \\
\hline $60+$ & 4 & 1.1 & 1-2 years & 10 & 2.9 \\
\hline Total & 348 & 100 & 2-3 years & 11 & 3.2 \\
\hline \multicolumn{3}{|c|}{ Monthly Income Level (JOD) } & $>3$ years & 321 & 92.2 \\
\hline Less than 400 & 71 & 20.4 & Total & 348 & 100 \\
\hline $400-600$ & 100 & 28.8 & \multicolumn{3}{|c|}{ Internet Experience } \\
\hline $601-800$ & 64 & 18.4 & $<$ One year & 9 & 2.6 \\
\hline $801-1000$ & 44 & 12.6 & $1-2$ years & 16 & 4.6 \\
\hline $1001-1200$ & 20 & 5.7 & $2-3$ years & 18 & 5.2 \\
\hline $1200+$ & 49 & 14.1 & $>3$ years & 305 & 87.6 \\
\hline Total & 348 & 100 & Total & 348 & 100 \\
\hline
\end{tabular}




\subsection{Structural Equation Modelling Analysis}

The two-stage approach, as recommended by Anderson and Gerbing (1982), was adopted in the current study. In the first stage (measurement model) followed by testing the structural model in the second stage.

\subsubsection{Measurement Model: Confirmatory Factor Analysis}

As shown in Table 2, the preliminary measurement fit indices were found as such: chi-square $\left(\chi^{2}=1635.893\right.$, degree of freedom $\left.(\mathrm{DF})=730, \quad \mathrm{P}<0.001\right)$ was significant; CMIN/DF=2.241; goodness-of-fit index $[\mathrm{GFI}]=0.812$; adjusted goodness-of-fit index $[\mathrm{AGFI}]=0.778$, root mean square error of approximation $[\mathrm{RMSEA}]=0.060$; normed-of-fit index $[\mathrm{NFI}]=0.868$; comparative fit index $[\mathrm{CFI}]=0.92$. Having a closer look at some of the fit indices (e.g. GFI, AGFI, NFI), the model does not seem to have adequate fit to data, and therefore, there is room for some re-specifications and refinement (Anderson and Gerbing, 1988; Byrne, 2010; Bagozzi and Yi, 1988). The revised measurement model was then examined without including the problematic items. The yielded fit indices indicted that the goodness of fit of the revised measurement model was adequately improved; all the fit indices this time were found within their recommended level as such: CMIN/DF was 1.849, $\mathrm{GFI}=0.908, \mathrm{AGFI}=0.873, \mathrm{NFI}=0.931, \mathrm{CFI}=0.967$ and $\mathrm{RMSEA}=0.049$ (see Table 2 ).

Table 2: Results of Measurement Model

\begin{tabular}{|l|c|c|c|}
\hline Fit indices & Cut-off point & $\begin{array}{l}\text { Initial measurement } \\
\text { model }\end{array}$ & $\begin{array}{l}\text { Modified measurement } \\
\text { model }\end{array}$ \\
\hline CMIN/DF & $\leq 3.000$ & 2.241 & 1.849 \\
\hline GFI & $\geq 0.90$ & 0.812 & 0.908 \\
\hline AGFI & $\geq 0.80$ & 0.778 & 0.873 \\
\hline NFI & $\geq 0.90$ & 0.868 & 0.931 \\
\hline CFI & $\geq 0.90$ & 0.920 & 0.967 \\
\hline RMSEA & $\leq 0.08$ & 0.060 & 0.049 \\
\hline
\end{tabular}

\subsubsection{Construct Reliability}

An examination of the construct reliability was conducted via testing the internal consistency (Cronbach's alpha), composite reliability (CR), and average variance extracted (AVE) for each construct (Anderson and Gerbing, 1988). As seen in Table 3, the extracted value of Cronbach's alpha for all constructs was found to be above their recommended level of 0.70 (Nunnally, 1978). Indeed, Cronbach's alpha was exhibited as a minimum 0.81 for adoption behaviour while the highest value was reached by PE with a value of 0.93 followed by BI with a value of 0.92 (see Table 3). As shown in Table 3, all latent constructs reflect an adequate composite reliability of at least 0.80 . Table 3 illustrates that both PE and BI had the 
highest value of 0.92 followed by HM and EE with the same value of 0.90 while the lowest value was observed regarding the adoption behaviour which was 0.80. The AVE for all latent constructs was estimated and found above the threshold value of 0.50 as well (Hair et al, 2010). The largest value of AVE was recorded by PE and BI with same value of 0.81; whereas, usage behaviour had the lowest AVE value of 0.57 (see Table 3).

Table 3: Constructs Reliability

\begin{tabular}{|l|c|c|c|}
\hline Variable & $\begin{array}{l}\text { Cronbach's } \\
\text { Alpha }(\alpha)\end{array}$ & $\begin{array}{l}\text { Composite Reliability } \\
(\mathrm{CR})\end{array}$ & $\begin{array}{l}\text { Average Variance } \\
\text { Extracted (AVE) }\end{array}$ \\
\hline PE & 0.93 & 0.92 & 0.81 \\
\hline EE & 0.90 & 0.90 & 0.75 \\
\hline SI & 0.85 & 0.85 & 0.74 \\
\hline FC & 0.87 & 0.86 & 0.70 \\
\hline HM & 0.90 & 0.90 & 0.81 \\
\hline PV & 0.88 & 0.87 & 0.78 \\
\hline HT & 0.87 & 0.86 & 0.75 \\
\hline PR & 0.88 & 0.87 & 0.62 \\
\hline BI & 0.92 & 0.92 & 0.80 \\
\hline UB & 0.81 & 0.80 & 0.57 \\
\hline
\end{tabular}

\subsubsection{Convergent Validity}

As seen in Table 3, all unremoved items were found to have standardised regression weights above the cut-off value of 0.50 and were statistically significant with the $p$ value less than 0.001 (Hair et al., 2010). An inspection of the correlation table provided in the AMOS output file revealed that all inter-correlation estimates were found to be less than threshold value of 0.85 (see Table 5) (Kline, 2005).

Table 4: Constructs Validity

\begin{tabular}{|c|c|c|c|c|}
\hline Latent Constructs & Items & $\begin{array}{c}\text { Factor } \\
\text { Loading }\end{array}$ & AVE & Square Root of AVE \\
\hline \multirow{3}{*}{ Performance Expectancy } & PE1 & 0.90 & \multirow{3}{*}{0.81} & \multirow{3}{*}{0.90} \\
\hline & PE2 & 0.90 & & \\
\hline & PE3 & 0.90 & & \\
\hline \multirow{3}{*}{ Effort Expectancy } & EE2 & 0.88 & \multirow{3}{*}{0.75} & \multirow{3}{*}{0.86} \\
\hline & EE3 & 0.87 & & \\
\hline & EE4 & 0.86 & & \\
\hline \multirow{2}{*}{ Social Influence } & SI1 & 0.82 & \multirow{2}{*}{0.74} & \multirow{2}{*}{0.86} \\
\hline & SI2 & 0.90 & & \\
\hline \multirow{3}{*}{ Facilitating Conditions } & FC1 & 0.76 & \multirow{3}{*}{0.70} & \multirow{3}{*}{0.83} \\
\hline & $\mathrm{FC} 2$ & 0.82 & & \\
\hline & FC3 & 0.91 & & \\
\hline \multirow{2}{*}{ Hedonic Motivation } & HM1 & 0.89 & \multirow{2}{*}{0.80} & \multirow{2}{*}{0.89} \\
\hline & HM2 & 0.91 & & \\
\hline \multirow{2}{*}{ Price Value } & PV2 & 0.90 & \multirow{2}{*}{0.78} & \multirow{2}{*}{0.88} \\
\hline & PV3 & .86 & & \\
\hline \multirow{2}{*}{ Habit } & HT1 & 0.89 & \multirow{2}{*}{0.75} & \multirow{2}{*}{0.86} \\
\hline & HT3 & 0.85 & & \\
\hline \multirow{4}{*}{ Perceived Risk } & PR2 & 0.77 & \multirow{4}{*}{0.62} & \multirow{4}{*}{0.78} \\
\hline & PR3 & 0.88 & & \\
\hline & PR4 & 0.95 & & \\
\hline & PR6 & 0.60 & & \\
\hline Behavioural Intention & BI1 & 0.88 & 0.80 & 0.89 \\
\hline
\end{tabular}




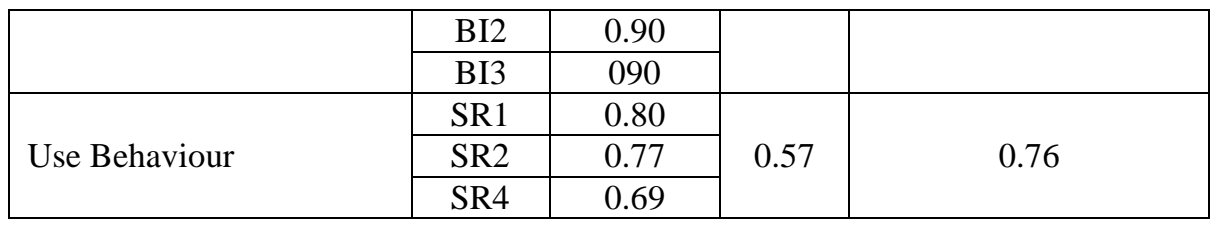

As shown in Table 4, the squared root of AVE exhibited for each latent construct was higher than the inter-correlation estimates with other corresponding constructs (Fornell and Larcker, 1981).

Table 5: Discriminant Validity

\begin{tabular}{|l|l|l|l|l|l|l|l|l|l|l|}
\hline Variable & PE & EE & SI & FC & HM & PV & HT & PR & BI & UB \\
\hline PE & $\mathbf{0 . 9 0}$ & & & & & & & & & \\
\hline EE & 0.66 & $\mathbf{0 . 8 6}$ & & & & & & & & \\
\hline SI & 0.59 & 0.59 & $\mathbf{0 . 8 6}$ & & & & & & & \\
\hline FC & 0.68 & 0.81 & 0.56 & $\mathbf{0 . 8 3}$ & & & & & & \\
\hline HM & 0.60 & 0.62 & 0.66 & 0.71 & $\mathbf{0 . 8 9}$ & & & & & \\
\hline PV & 0.60 & 0.58 & 0.60 & 0.70 & 0.66 & $\mathbf{0 . 8 8}$ & & & & \\
\hline HT & 0.61 & 0.55 & 0.59 & 0.55 & 0.60 & 0.67 & $\mathbf{0 . 8 6}$ & & & \\
\hline PR & -0.40 & -0.37 & -0.40 & -0.45 & -0.42 & -0.46 & -0.45 & $\mathbf{0 . 7 8}$ & & \\
\hline BI & 0.65 & 0.65 & 0.60 & 0.70 & 0.70 & 0.68 & 0.55 & -0.55 & $\mathbf{0 . 8 9}$ & \\
\hline UB & 0.49 & 0.41 & 0.36 & 0.52 & 0.45 & 0.46 & 0.60 & -0.28 & 0.57 & $\mathbf{0 . 7 6}$ \\
\hline
\end{tabular}

Note: Diagonal values are squared roots of AVE; off-diagonal values are the estimates of inter-correlation between the latent constructs.

\subsubsection{Common Method bias}

To avoid any problem related to common method bias, researchers applied Harman's singlefactor test with 10 factors and 40 items. 45 items were loaded into exploratory factor analysis and inspected using an unrotated factor solution. About 38.246 per cent that was recorded as a variance in the first factors which is not more than 50 per cent that recommended by Podsakoff et al. (2003). Therefore, the data set of Internet banking does not have any concerns regarding the common method bias.

\subsubsection{Structural Model}

As summarised in Table 6, the main statistical results indicated that despite the fact that the Chi-square was significant $\left(\chi^{2}=666.733, \mathrm{DF}=293, \mathrm{P}=0.000\right)$, the rest of the fit indices of the structural model were found to be within their threshold values as such CMIN/DF was 2.276, GFI $=0.901, \mathrm{AGFI}=0.841, \mathrm{NFI}=0.921, \mathrm{CFI}=0.95$ and $\mathrm{RMSEA}=0.061$. Thus, suggesting that structural model adequately fit the data. Moreover, statistical results largely supported the conceptual model via explaining $64 \%, 32 \%, 52 \%$, and $52 \%$ of variance in behavioural intention; usage behaviour, performance expectancy, and price value respectively (see Figure 2).

Table 6: Fit Indices of Structural Model

\begin{tabular}{|l|l|l|}
\hline Fit indices & Cut-off point & Structural model \\
\hline
\end{tabular}




\begin{tabular}{|l|c|c|}
\hline CMIN/DF & $\leq 3.000$ & 2.276 \\
\hline GFI & $\geq 0.90$ & 0.901 \\
\hline AGFI & $\geq 0.80$ & 0.841 \\
\hline NFI & $\geq 0.90$ & 0.921 \\
\hline CFI & $\geq 0.90$ & 0.950 \\
\hline RMSEA & $\leq 0.08$ & 0.061 \\
\hline
\end{tabular}

With regard to the path coefficients analyses, the coefficient values of the paths ending to behavioural intention including performance expectancy $(\gamma=0.14, p<0.026)$; effort expectancy $(\gamma=0.19, \mathrm{p}<0.002)$; hedonic motivation $(\gamma=0.30, \mathrm{p}<0.001)$; price value $(\gamma=0.15, \mathrm{p}<0.006)$; perceived risk $(\gamma=-0.22, \mathrm{p}<0.001)$ were found to be statistically significant (see Figure 2$)$. Yet, the path coefficient of social influence $(\gamma=0.031, \mathrm{p}=0.645)$ on behavioural intention was recognised as non-significant. The path coefficients starting with performance expectancy $(\gamma=0.30, \mathrm{p}<0.000)$ and hedonic motivation $(\gamma=0.50, \mathrm{p}<0.001)$ and ending in price value were found statistically significant as well. Both effort expectancy $(\gamma=0.48, p<0.001)$ and hedonic motivation $(\gamma=0.32, p<0.001)$ were found to have a significant influence on the performance expectancy. Moreover, facilitating conditions $(\gamma=0.18, \mathrm{p}<0.035)$, behavioural intention $(\gamma=0.33, p<0.001)$, and habit $(\gamma=0.24, p<0.004)$ all had statistically significant path coefficients on adoption behaviour (see Figure 1). Therefore, except H5 (SI $\rightarrow$ BI), all research hypothesises $(\mathrm{H} 1, \mathrm{H} 2, \mathrm{H} 3, \mathrm{H} 4, \mathrm{H} 6, \mathrm{H} 7, \mathrm{H} 8, \mathrm{H} 9, \mathrm{H} 10, \mathrm{H} 11, \mathrm{H} 12$, and H13) were supported (see Table 7).

Table 7 Results of Standardised Estimates of Structural Model

\begin{tabular}{|l|c|c|c|c|}
\hline Path & $\begin{array}{c}\text { Path } \\
\text { Coefficients }\end{array}$ & $\begin{array}{c}\text { P- } \\
\text { value }\end{array}$ & VIF & $\begin{array}{c}\text { Significance? } \\
\text { [YES/NO] }\end{array}$ \\
\hline $\mathrm{PE} \rightarrow \mathrm{BI}$ & 0.14 & 0.026 & 2.009 & YES \\
\hline $\mathrm{PE} \rightarrow \mathrm{PV}$ & 0.30 & $* * *$ & 1.978 & YES \\
\hline $\mathrm{EE} \rightarrow \mathrm{BI}$ & 0.19 & 0.002 & 2019 & YES \\
\hline $\mathrm{EE} \rightarrow \mathrm{PE}$ & 0.27 & $* * *$ & 1.941 & YES \\
\hline $\mathrm{SI} \rightarrow \mathrm{BI}$ & 0.03 & 0.645 & 1.547 & NO \\
\hline $\mathrm{HM} \rightarrow \mathrm{BI}$ & 0.30 & $* * *$ & 2.014 & YES \\
\hline $\mathrm{HM} \rightarrow \mathrm{PE}$ & 0.32 & $* * *$ & 1.984 & YES \\
\hline $\mathrm{HM} \rightarrow \mathrm{PV}$ & 0.50 & $* * *$ & 2.125 & YES \\
\hline $\mathrm{PV} \rightarrow \mathrm{BI}$ & 0.15 & 0.006 & 2.871 & YES \\
\hline $\mathrm{FC} \rightarrow$ Adoption & 0.18 & 0.035 & 1.847 & YES \\
\hline $\mathrm{HT} \rightarrow$ Adoption & 0.24 & 0.004 & 1.874 & YES \\
\hline $\mathrm{PR} \rightarrow$ BI & -0.22 & $* * *$ & 1.258 & YES \\
\hline $\mathrm{BI} \rightarrow$ Adoption & 0.33 & $* * *$ & 2.002 & YES \\
\hline
\end{tabular}

5.2.6 Multi collinearity test

Statistical results regarding Multi collinearity test assured that there is no concern regarding multi collinearity as all values of variance inflation factors (VIF) were observed to 
be within the acceptable value of 10 (Brace et al., 2003; Diamantopoulos and Winklhofer, 2001).

\section{Discussion}

As presented in the prior section, the main results of the revised version of measurement model (i.e. model fitness, constructs reliability, and constructs validity) and the structural model (model fitness and predictive validity) strongly support the conceptual model proposed in Section 3. In detail, as seen in Table 1 and Table 6, all fit indices: CMIN/DF, GFI, AGFI, NFI, CFI, and RMSEA) for both measurement model and structural model were found to be within their threshold values. Further, it could be clearly acknowledged that all ten constructs (PE, EE, SI, FC, HM, PV, HT, PR, BI, and, adoption) were able to satisfactorily meet the construct reliability criteria by having an adequate level of internal consistency (Alpha value above 0.81); sufficient value of CR (as low as 0.80); and an acceptable value of AVE (higher than 0.57 ).

It is also worth mentioning that the main constructs of the UTAUT2 (without the perceived risk) were able to predict about $58 \%$ of variance in behavioural intention. However, $R^{2}$ values accounted for behavioural intention were enhanced by the inclusion of perceived risk along with the UTAUT2 constructs in the same structural model $(58 \%$ per cent vs 64 per cent with perceived risk). Accordingly, it could be concluded that the structural model seems to have more power in predicting the behavioural intention once perceived risk is comprised together with the UTAUT2 constructs. Similar findings from Martins et al. (2014) approved the impact of including perceived risk beside the UTAUT constructs (PE, EE, SI, FC) on the $R^{2}$ value extracted for behavioural intention to use Internet banking.

As seen in Table 7, the all research hypotheses proposed were supported except one hypothesis (H5: social influence $\rightarrow$ behavioural intention). As seen in Figure 2, hedonic motivation seems to be the most influential factor contributing the Jordanian customers'. This means that those participants, who perceive using IB could comprise further intrinsic utilities to them, are more likely to be motivated to adopt such technology. By the same token, there are several instances in the prior literature that have examined and approved hedonic motivation or its similar factors (e.g. fun, enjoyment, playfulness and perceived entertainment) on the customers' intention to use technology (Alenezi et al., 2017; Dabholkar and Bagozzi, 2002; Dabholkar et al., 2003; Esman et al., 2010; Gan et al., 2006; Orel and Kara., 2014). This study also was able to provide empirical evidences confirming the 
significant influence of hedonic motivation on price value and performance expectancy. In other words, IB was found to be highly perceived as useful and having a price value among those customers who perceive using such channel comprising of further enjoyment and entertainment. Having further intrinsic utilities in using new system strengthens the perception that the targeted system is more productive and cost-effective and, as a result, contributing to value perceived by using such a system (e.g. performance expectancy, price value) (Cheng et al., 2006; Moon and Kim, 2001; Venkatesh, 2000).

The empirical results have supported the significant relationship between effort expectancy and behavioural intention to adopt Internet banking. Thus, respondents are more likely to have a higher intention to adopt IB if they perceive that the use of these technologies is not difficult and require little effort. These results are consistent with existing literature in the information system area (e.g. Venkatesh et al., 2003; Venkatesh et al., 2012) and in the IB context as well. Effort expectancy was also proposed to be a key predictor of performance expectancy. Expectedly, empirical results confirmed a strong correlation between effort expectancy and performance expectancy. As discussed by prior studies on the information system, customers usually are involved in a cognitive trade-off process between the utilities expected from using technology and the effort that should be done to use this technology (Celik, 2008; Davis et al., 1989; Eriksson et al., 2005; Kim and Forsythe, 2010; Wang et al., 2003).

In line with Venkatesh et al. (2012), price value was empirically confirmed to be a significant factor determining behavioural intention to adopt Internet banking. It demonstrated that Jordanian customers are more concerned about the monetary value in formulating their intention to use or reject Internet banking. To put differently, respondents seem to be more inspired to use the IB if the utilities attached to such system are perceived to be higher than the monetary cost paid. This relationship could be attributed to the fact that customers are really interested in the monetary benefits of using new innovations as long as their interest in the extrinsic utilities (performance expectancy) and intrinsic utilities (hedonic motivation) have been confirmed as has been mentioned earlier in this study. This is in line with Venkatesh et al.'s (2012) thought ensuring that the financial issues usually draw considerable attention to the customer context rather than the organisational context where the cost is comprised in terms of time and effort. These results are in line with what has been proven by prior studies addressing the important role of price and perceived value (Al-Hawari and 
Ward, 2006; Ding et al., 2007; Gerrard and Cunningham, 2003; Ho and Ko, 2008; Howcroft et al., 2002; Lee and Allaway, 2002; Meuter et al., 2000).

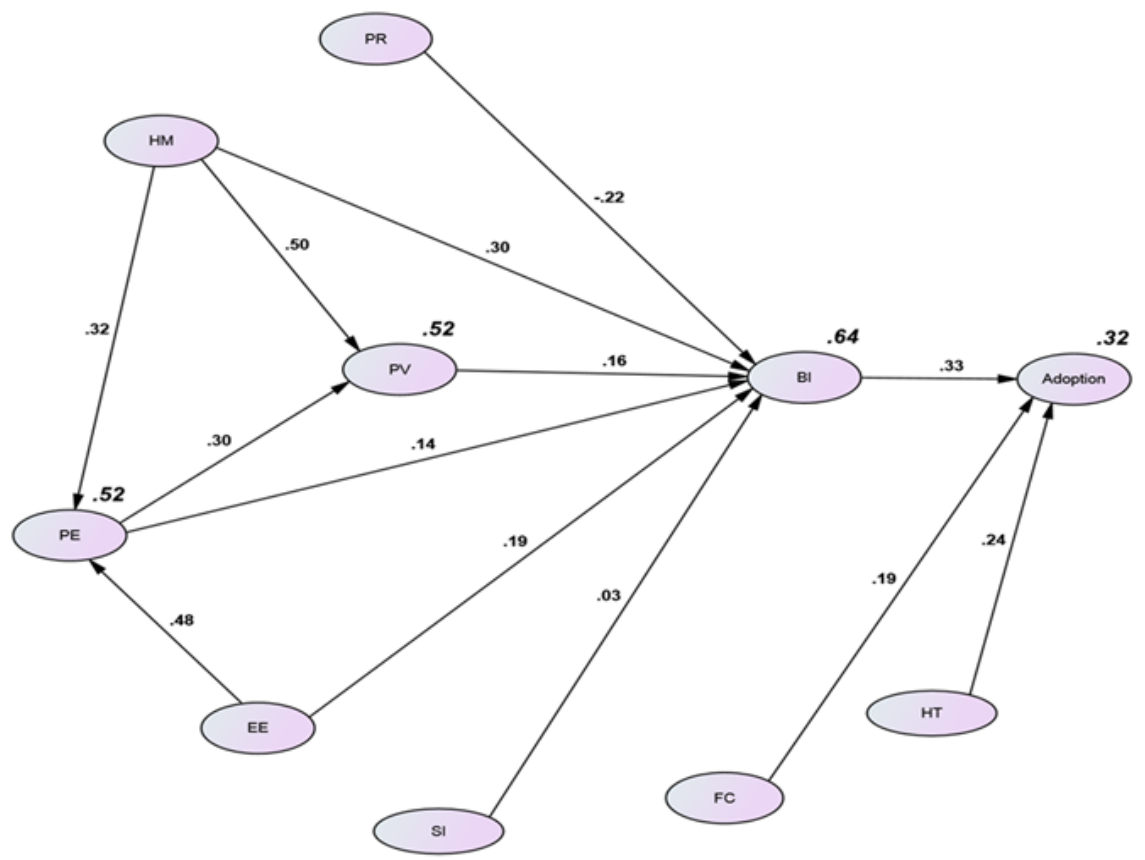

Figure 2: Validated Conceptual Model

Performance expectancy has been able to maintain its significant impact on the customers' intention to adopt Internet banking. In other words, Jordanian customers seem to be more motivated to adopt IB channels if they perceive that such channel is more effective, productive, and a useful technology in their daily life. This could be attributed to the ability of IB as a convenient way of allowing customers to access a wide range of higher quality financial services (i.e. balance enquiries, fund transfers, paying bills) without any time or place restrictions (Curran and Meuter, 2005). Furthermore, IB has been widely recognised as the most integral, innovative, productive, and friendliest technologies to contribute to the customers' life in comparison with the traditional encounter which usually requests further time and effort from customers to obtain the same services (Aladwani, 2001; Karjaluoto et al., 2002; Lassar et al., 2005; Lee, 2009; Liao et al., 1999).

The statistical findings have highly supported performance expectancy for playing a significant role in contributing to the price value related to using Internet banking. In other words, for those customers who perceive IB as a useful technology in contributing to their daily life with several benefits (e.g. efficiency, convenience, time- and effort-saving), they are more likely to perceive IB more valuable instead of the monetary cost paid (Ho and Ko, 
2008; Kuo et al., 2009; Laukkanen and Kantanen, 2006; Wang et al., 2004; Zhu and Chen, 2012).

This study, as presented in prior section, empirically proved perceived risk as a significant factor negatively determining the behavioural intention to adopt IB $(\gamma=-0.22 ; p<0.001)$. Accordingly, it could be concluded that perceived risk is an important aspect considered by Jordanian customers in formulating their intention to use or reject Internet banking. In addition, the negative sign of the relationship between perceived risk and behavioural intention indicates that customers are less likely to be encouraged to use these channels with a higher degree of expectation of suffering a loss. In the Jordanian context, perceived risk and the lack of security assurance represent the main concern and apprehension mitigating Jordanian customers' willingness to adopt these banking channels. This negative role of perceived risk has been empirically supported by most studies conducted in the Jordanian context (Awwad and Ghadi, 2010; Khraim et al., 2011; Al-Majali, 2011; Al-Smadi, 2012; Al Sukkar and Hasan, 2005). This could be attributed to the increase in the rate of cybercrimes related to online transactions in Jordan and the Middle East in general; over the last decade it has been accompanied by a heavy concentration of media on such issues (Alghad, 2014; BBC Arabic, 2009; Faqir, 2013; The Jordan Times, 2014). For instance, according to a report cited by Faqir (2013), there has been a noticeable increase in the rate of cybercrimes registered in Jordan; by the end of 2011 there was in excess of 1,103 cases stated by the Ministry of Communications and Information Technology (Faqir, 2013). This, in turn, leaves a negative effect in the minds of Jordanian banking customers who use these channels; it could expose them further by jeopardising and threatening the safety of their money and their own information and privacy.

However, the empirical results of this study indicated that the path coefficient between social influence and behavioural intention was found to be non-significant. The non-significant impact of social influence means that respondents are not concerned about the aspects associated with social factors in forming their intention to adopt IB.

Arguably, the important and natural role of social influence in shaping behavioural intention to use new innovations has been observed varying over the prior literature of online banking technologies. This variation could be attributed to the nature of the context where technology is being examined (mandatory versus voluntary); the level of development in the country (developing country versus developed country); nature of technology (individual and personal technology versus common and sociable technology); and individual attitude, 
perception, experience, and skills regarding the technology of interest (Burton-Jones and Hubona, 2006; Davis et al., 1989; Malaquias and Hwang, 2016; Malhotra and Galletta, 1999; Oliver and Dearden, 1985; Titah and Barki, 2009; Venkatesh and Davis, 2000). For instance, Titah and Barki (2009) argued further on the substitute role of the subjective norm and the attitudes to predict and formulate the behavioural intention towards technology. Indeed, Titah and Barki (2009, p.829) stated that "an increase in subjective norms will reduce the marginal impact of an increase in positive attitude, and an increase in positive attitude will reduce the marginal impact of an increase in subjective norms".

In line with Venkatesh et al. (2012), facilitating conditions were empirically confirmed to be a significant factor predicting the actual adoption of IB by Jordanian banking customers. This means that Jordanian customers are more concerned about the facilities, resources, and skills that are needed to conduct the IB services. This relationship could be attributed to the fact that the nature of the facilities that are required in the case of IB (i.e. PC, Internet access, Wi$\mathrm{Fi}$, secured websites) are fundamental aspects for IB users to have a smooth, safe, and easy access to the financial services. These results are in the line with what has been proven by prior studies addressing the important role of facilitating conditions (Wang and Shih, 2009; Zhou et al., 2010).

As shown in Figure 2, habit was found to be the second strongest factor predicting the actual adoption of IB by Jordanian banking customers. This means that the extent of using IB services reaches the highest level among those customers who have already formulated habitual behaviour toward such technology. Such results are in the line with what has been proposed by Venkatesh et al. (2012). Contributions to Theory

Results of the current study have profoundly contributed to the area of the information system and IB by extending the current understanding regarding such important phenomena of interest as well as providing valuable insights for academic perspective. Firstly, this study critically reviews and evaluates the most common models and theories in the technology acceptance field. Significantly, almost all theories conducted to explain the customers' intention and adoption of IB have been originally proposed and examined in an organisational context (Venkatesh et al., 2003; Venkatesh et al., 2012). This, in turn, creates a concern regarding the applicability of these theories over the customer contexts (Venkatesh et al., 2012). Due to the fact that the UTAUT2 is specifically proposed to clarify the adoption of new systems according to the customers' perspective (Venkatesh et al., 2012), it was chosen as an appropriate guiding theory for proposing the conceptual model of the current study. 
Thus, a considerable contribution was captured by the current study for being the initiating study that has extended the validity to examine a new technology (i.e. Internet banking) over the Jordanian customers as developing country.

Even though the UTAUT2 successfully introduced an adequate view of clarifying customers' intention and behaviour towards technology, proposing a model capable of interpreting customers' intention and behaviour towards sensitive technology (e.g. IB as self-service technology) calls for integrating new factors and modifying new relationships.

Thus, the UTAUT2 was extended by including perceived risk. Indeed, perceived risk is one of the most frequently used and predictive factors that was proposed along with UTAUT2 factors in the same conceptual model which, in turn, demonstrates a significant contribution to the expansion of the theoretical horizon of the UTAUT2. While Venkatesh et al. (2012) discussed how functional, intrinsic, and financial utilities can directly predict behavioural intentions; this study added a contribution to UTAUT2 by discussing causal interactions between these aspects. Such as, this study provides new trends via examining the impact of hedonic motivation on price value and performance expectancy as well as proposing a direct path from performance expectancy to price value. This is, further, representing a worthwhile direction to be examined and verified in future studies for other SST channels (i.e. online line hotel booking, mobile payment, Mobile banking) or in a different context to see if these paths will behave in the same manner which has been observed in this study or not.

As discussed before, the majority of these studies have discussed the negative impact of habitual behaviour related with traditional banking channels on the customers' tendency to adopt the electronic channels (Kuisma et al., 2007; Laukkanen et al., 2008). However, the positive role of habit as proposed by Venkatesh et al. (2012) has not been covered by prior IB studies. Thus, current study was able to comprise a significant contribution by focusing more new mechanism pertaining to automaticity behaviour.

\subsection{Implications to Practice}

The implementation of IB is not feasible unless customers widely adopt these technologies as full alternatives for human encounters (Meuter et al., 2005; Simintiras et al., 2014). Consequently, undertaking an empirical study helps to identify the most important aspects, and accordingly, altering banks in Jordan to implement effective and appropriate marketing strategies to enhance the adoption of such innovative services by customers (Gumussoy, 2016). For instance, the significant influence of behavioural intention on the 
adoption behaviour clearly implies that most of the respondents have a higher willingness to adopt IB which, in turn, could be considered as worthwhile potential and interested adopters (Dwivedi and Irani, 2009; Irani et al., 2009). In addition to this, most of them enjoy an adequate level of education and experience with the Internet and the computer; moving them to be actual users of SSTs will not be expensive and difficult (Akinci et al., 2004). In this respect, conducting a personal contact with those customers could be an effective approach to convince such customers to use IB as a channel saving their time and efforts (Laukkanen et al., 2009).

Hedonic motivation was also found to be playing a crucial role; not only in enhancing the behavioural intention but also contributing to a better performance as well as contributing to price value that is gained by using Internet banking. Therefore, any marketing plan should pay a particular interest in the aspects that contribute to hedonic motivation. For instance, by conducting a well-designed campaign, banks could contribute to the perception of these channels as a more novel and innovative technology and, thereby, contributing to hedonic motivation (Irani et al., 2009; Venkatesh et al., 2012).

Jordanian banks could also make use of developments in the social media to undertake their campaigns in a more persuasive, advanced and economical way (Chen et al., 2014; $\mathrm{Yu}$, 2012). Indeed, social media tools (i.e. YouTube, Facebook, and Twitter) characterise a higher degree of accessibility; anybody nowadays can easily access such applications (Berthon et al., 2012). This is in addition to the fact that these applications are extensively adopted by people around the world (i.e. 1.47 billion have used social media applications by 2012 as published by eMarketer (2013). Thus, using social media applications to promote the adoption of IB will help Jordanian banks to reach a larger number of banking customers in a more accessible, cost-effective and easier way (Berthon et al., 2012). More importantly, banks need to convince their customers who use IB that it is now a basic requirement of a modern lifestyle; it represents an interesting experience along with saving time and cost; and using these channels such as smartphones, Internet, e-mail, and social media is considered a normal extension for other innovations that could be used by customers (Hwang and Kim, 2007; Irani et al., 2009; Lassar et al., 2005; Shareef et al., 2011; Simintiras et al., 2014).

Facilitating conditions were found to be key predictors of adoption behaviour toward Internet. Thus, further interest by banks in improving the facilities required to effectively use IB will not only enhance the online banking acceptance but will also simplify accessing the benefits and utilities of using this technology as well as contributing to price value. Initially, 
banks need to concentrate on providing IB channels in a compatible manner with other common technologies used by customers along with convincing them that using these channels is not far different from other technologies (Simintiras et al., 2014).

Finally, this study shows that perceived risk was a significant factor hindering behavioural intention. Practically, there are several recommended strategies that could be applied by banks to reduce the perceived risks associated with the use of electronic banking channels (Laukkanen et al., 2007; Laukkanen et al., 2009; Poon, 2008; Simintiras et al., 2014; Tan, 1999; Yousafzai et al., 2005). As with any other aspects discussed before, banks have to spend more educational efforts persuading users that IB is fully protected and are a less risky way to attain the financial services (Laukkanen et al., 2008; Simintiras et al., 2014). Banks should also train their customers on how they can safely use online channels and how they can cope with any suspicious and/or hacking regarding their account.

Furthermore, deriving feedback from customers regarding the most critical risks that tend to increase customers' concerns in using IB (e.g. financial, image, social, performance) could help banks to choose the most suitable strategy to mitigate these concerns (Martins et al., 2014). In the case of the current study, it seems that Jordanian customers have expressed their concerns regarding privacy, financial and performance risk. Also, the presence of viruses and Trojan horses through Internet might also show great uncertainty and risk linked with using Internet banking (Zhou, 2012). This thought was supported by the strong statistical impact of perceived risk on the Jordanian customers' intention to adopt Internet banking. Therefore, as suggested by Laukkanen et al. (2008), using an innovative modification strategy is more applicable in this respect. According to this strategy, banks are highly recommended to utilise a form of advancement in the biometric technology area, which introduces many solutions and tools to improve the customers' authentication mechanisms (e.g. fingerprints, voice tag, and iris recognition) (Laukkanen et al., 2008; Poon, 2008; Salomann et al., 2006; Simintiras et al., 2014). For instance, using the biometric technology application (e.g. iris recognition) for IB to verify any transactions would provide further simplicity and a safe way to approach bank accounts rather than using the traditional password method (Laukkanen et al., 2008; Poon, 2008). Other strategies that could be more useful in mitigating perceived risks include a money-back guarantee policy in the case of fraud; along with improving a structural assurance to prevent any hacking and piracy processes (Gan et al., 2006; Martins et al., 2014; Simintiras et al., 2014; Yousafzai et al., 2005). 


\section{Conclusion}

This study was conducted with the aim to clarify and identify the main factors shaping the Jordanian customers' intention and adoption of IB. According to the prior literature regarding IB and adoption of such technology in Jordan, it was noticed that there is a need to select a theoretical foundation, which can explain the adoption of IB from the customer's perspective. Therefore, the proposed conceptual model was built based on the UTAUT2. This was also extended by introducing new causal paths among UTAUT2 constructs and including perceived risk as external factor. Data for the current study was collected from 348 Jordanian banking customers who already have adopted IB. The main statistical results highly supported the conceptual model by predicting $64 \%$ of variance in the behavioural intention. The UTAUT2 factors namely, performance expectancy, effort expectancy, hedonic motivation and price value were able to significantly predict the customer intention. Yet, social influence was not found significant on behavioural intention. By doing so, current study was able to provide both academics and practitioners a significant contribution.

\subsection{Limitations and Future Research Directions}

The main focus of the current study was on applying the quantitative approach to achieve the research aim. This, in turn, could have constrained the ability of the current study to have a closer look by clarifying more of the issues related to the Jordanian customers' intention and behaviour towards Internet banking. Therefore, conducting a mixed-method approach (quantitative and qualitative) could provide a more detailed explanation of the current study's results particularly regarding those non-significant relationships.

This study concentrated on adopters and potential adopters of IB while it ignored other types of customers who rejected using Internet banking; for example, postponers, opponents, and rejecters (Laukkanen et al., 2008). However, studying those kinds of customers could help to have a further understanding about the main obstacles hindering the IB acceptance. In addition, this study fully focused on the customers' perspective; yet, it has not looked at this problem from the service providers' perspective. Therefore, this could be a limitation for not providing a full picture of clarifying the main aspects related to the successful implementation and adoption of IB from both sides i.e., customers and service providers (banks).

Further, the demographic differences (e.g. age, gender, technology experience) could reflect different levels of the impacting role of social influence on the behavioural intention 
(Algharabat et al., 2017; Constantiou et al., 2009; Venkatesh et al., 2003). Therefore, the moderating influence of age, gender, and experience on the relationship between social influence and behavioural intention should derive further attention to future studies.

\section{References}

AbuShanab, E., Pearson, M. and Setterstrom, A. J. (2010). Internet banking and customers' acceptance in Jordan: The unified model's perspective. Communications of the Association for Information Systems, 26(1), 493-524.

Agarwal, R. and Karahanna, E. (2000). Time flies when you're having fun: Cognitive absorption and beliefs about information technology usage. MIS Quarterly, 24(4), 665-694.

Ajzen, I. (1985). From intentions to actions: A theory of planned behavior. In J. Kuhland J. Beckman (Eds.), Action-Control: From Cognition to Behavior (pp. 11-39). Heidelberg: Springer,

Akhlaq, A. and Ahmed, E. (2013). The effect of motivation on trust in the acceptance of internet banking in a low income country. International Journal of Bank Marketing, $31(2), 115-125$.

Akinci, S., Aksoy, S., and Atilgan, E. (2004). Adoption of internet banking among sophisticated consumer segments in an advanced developing country. International Journal of Bank Marketing, 22(3), 212-232.

Alalwan, A. A., Dwivedi, Y. K., and Rana, N. P. (2017). Factors influencing adoption of mobile banking by Jordanian bank customers: Extending UTAUT2 with trust. International Journal of Information Management, 37(3), 99-110.

Alalwan, A. A., Dwivedi, Y. K., and Williams, M. D. (2016a). Customers' intention and adoption of telebanking in Jordan. Information Systems Management, 33(2), 154-178.

Alalwan, A. A., Dwivedi, Y. K., Rana, N. P., and Simintiras, A. C. (2016c). Jordanian consumers' adoption of telebanking: Influence of perceived usefulness, trust and selfefficacy. International Journal of Bank Marketing, 34(5), 690-709.

Alalwan, A. A., Dwivedi, Y. K., Rana, N. P., and Williams, M. D. (2016b). Consumer adoption of mobile banking in Jordan: Examining the role of usefulness, ease of use, perceived risk and self-efficacy. Journal of Enterprise Information Management, 29(1), 118-139.

Alalwan, A. A., Dwivedi, Y. K., Rana, N. P., Lal, B., and Williams, M. D. (2015). Consumer adoption of Internet banking in Jordan: Examining the role of hedonic motivation, habit, self-efficacy and trust. Journal of Financial Services Marketing, 20(2), 145-157.

Alenezi, H., Tarhini, A., Masa'deh, R. E., Alalwan, A., and Al-Qirim, N. (2017). Factors Affecting the Adoption of e-Government in Kuwait: A Qualitative Study. Electronic Journal of e-Government, 15(2).

Al-Gahtani, S. S. (2011). Modelling the electronic transactions acceptance using extended technology acceptance model. Applied Computing and Informatics, 9(1), 47-77.

Alghad (2014). 400 cybercrime within three months. Available from: http://www. alghad.com/articles/513291-400. Accessed: 16.06.16.

Algharabat, R., Alalwan, A. A., Rana, N. P., and Dwivedi, Y. K. (2017). Three dimensional product presentation quality antecedents and their consequences for online retailers: The moderating role of virtual product experience. Journal of Retailing and Consumer Services, 36, 203-217. 
Al-Hawari, M. and Ward, T. (2006). The effect of automated service quality on Australian banks' financial performance and the mediating role of customer satisfaction. Marketing Intelligence \& Planning, 24(2), 127-147.

Al-Hawari, M., Ward, T., and Newby, L. (2009). The relationship between service quality and retention within the automated and traditional contexts of retail banking. Journal of Service Management, 20(4), 455-472.

Al-Majali, M. (2011). The use of theory reasoned of action to study information technology in Jordan. Journal of Internet Banking and Commerce, 16(2), 1-13.

Al-Qeisi, K. and Abdallah, G. (2013). Internet banking adoption in Jordan: A behavioral approach. International Journal of Marketing Studies, 5(6), 84-107.

Al-Rfou, A. N. (2013). The usage of Internet banking evidence from Jordan. Asian Economic and Financial Review, 3(5), 614-623.

Al-Smadi, M. O. (2012). Factors affecting adoption of electronic banking: An analysis of the perspectives of banks' customers. International Journal of Business and Social Science, 3(17), 294-309.

Al-Somali, S., Gholami, R. and Clegg, B. (2009). An investigation into the acceptance of online banking in Saudi Arabia. Journal of Business Research, 29(2), 130-141.

Anderson, J. C. and Gerbing, D. W. (1988). Structural equation modelling in practice: A review and recommended two-step approach. Psychological Bulletin, 103(3), 411423.

Awwad, M. S. and Ghadi, M. Y. (2010). Investigating of factors influencing the intention to adopt mobile banking services in Jordan. Dirasat: Administrative Sciences, 37(2), 545-556.

Baabdullah, A., Nasseef, O., and Alalwan, A. (2016, September). Consumer Adoption of Mobile Government in the Kingdom of Saudi Arabia: The Role of Usefulness, Ease of Use, Perceived Risk and Innovativeness. In Conference on e-Business, e-Services and e-Society (pp. 267-279). Springer International Publishing.

Bagozzi, R. P. and Yi, Y. (1988). On the evaluation of structural equation models. Journal of the Academy of Marketing Science, 16(1), 74-94.

Bandura, A. (1982). Self-efficacy mechanism in human agency. American Psychologist, $37(2), 122-147$.

Baptista, G., and Oliveira, T. (2015). Understanding mobile banking: The unified theory of acceptance and use of technology combined with cultural moderators. Computers in Human Behavior, 50, 418-430.

BBC Arabic. (2009). Start using Iris recognition technology in ATMS by the Jordanian banks. Available from: http://www.bbc.co.uk/arabic/middleeast/2009/10/091013_om_ jordan_bank_tc2.shtml. Accessed: 16.09.16.

Berger, S. C. (2009). Self-service technology for sales purposes in branch banking: The impact of personality and relationship on consumer adoption. International Journal of Bank Marketing, 27(7), 488-505.

Boateng, H., Adam, D. R., Okoe, A. F., and Anning-Dorson, T. (2016). Assessing the determinants of internet banking adoption intentions: A social cognitive theory perspective. Computers in Human Behavior, 65, 468-478.

Brislin, R. (1976). Comparative research methodology: Cross-cultural studies. International Journal of Psychology, 11(3), 215-229.

Brown, M., Pope, N., and Voges, K. (2003). Buying or browsing? An exploration of shopping orientations and online purchase intention. European Journal of Marketing, 37(10/11), 1666-1684. 
Brown, S. A. and Venkatesh, V. (2005). Model of adoption of technology in the household: A baseline model test and extension incorporating household life cycle. MIS Quarterly, 29(4), 399-426.

Burton-Jones, A. and Hubona, G. S. (2006). The mediation of external variables in the technology acceptance model. Information \& Management, 43(6), 706-717.

Byrne, B. (2010). Structural equation modeling with AMOS: Basic concepts, applications and programming. ( $6^{\text {th }}$ edition). New York, USA: Taylor \& Francis Group.

Casaló, L. V., Flavián, C. and Guinalíu, M. (2007). The role of security, privacy, usability and reputation in the development of online banking. Online Information Review, 31(5), 583-603.

Celik, H. (2008). What determines Turkish customers' acceptance of internet banking? International Journal of Bank Marketing, 26(5), 353-370.

Cheng, J. M., Sheen, G. J., and Lou, G. C. (2006). Consumer acceptance of the Internet as a channel of distribution in Taiwan - a channel function perspective. Technovation, 26(7), 856-864.

Childers, T. L., Carr, C. L., Peck, J., and Carson, S. (2002). Hedonic and utilitarian motivations for online retail shopping behavior. Journal of Retailing, 77(4), 511-535.

Compeau, D. and Higgins, C. (1995) Application of social cognitive theory to training for computer skills. Information Systems Research, 6(2), 118-143.

ComScore. (2012). 1 in 4 Internet users access banking sites globally. Available from: https://www.comscore.com/Insights/Data-Mine/1-in-4-Internet-Users-AccessBanking-Sites-Globally. Accessed: 14.08.16.

Constantiou, I. D., Papazafeiropoulou, A., and Vendelo, M. T. (2009). Does culture affect the adoption of advanced mobile services? A comparative study of young adults' perceptions in Denmark and the UK. ACM SIGMIS Database, 40(4), 132-147.

Cuevas, J. (1998). The Internet banking horizon: Bleak or bright for community banks?. Journal of Internet Banking and Commerce, 3(3), 9811-9814.

Curran, J. M. and Meuter, M. L. (2005). Self-service technology adoption: Comparing three technologies. Journal of Services Marketing, 19(2), 103-113.

Curran, J. M. and Meuter, M. L. (2007). Encouraging existing customers to switch to selfservice technologies: Put a little fun in their lives. Journal of Marketing Theory and Practice, 15(4), 283-298.

Davis, F. D. and Venkatesh, V. (2004). Toward pre-prototype user acceptance testing of new information systems: implications for software project management. Engineering Management, IEEE Transactions, 51(1), 31-46.

Demirci Orel, F. D. and Kara, A. (2014). Supermarket self-checkout service quality, customer satisfaction, and loyalty: Empirical evidence from an emerging market. Journal of Retailing and Consumer Services, 21(4), 188-129.

Department of Statistics. (2015). Statistical Year Book 2013. Available from: http://www. dos.gov.jo/dos_home_a/main/yearbook_2013.pdf. Accessed: 08.03.16.

DeYoung, R., Lang, W. W., and Nolle, D. L. (2007). How the Internet affects output and performance at community banks. Journal of Banking and Finance, 31(4), 10331060.

Dodds, W. B., Monroe, K. B., and Grewal, D. (1991). Effects of price, brand, and store information on buyers. Journal of Marketing Research, 28(3), 307-319.

Dwivedi, Y. K. and Irani, Z. (2009). Understanding the adopters and non-adopters of broadband. Communications of the ACM, 52(1), 122-125.

Dwivedi, Y. K. and Irani, Z. (2009). Understanding the adopters and non-adopters of broadband. Communications of the ACM, 52(1), 122-125. 
Dwivedi, Y. K., Choudrie, J. and Brinkman, W. P. (2006). Development of a survey instrument to examine consumer adoption of broadband. Industrial Management and Data Systems, 106(5), 700-718.

Dwivedi, Y.K., Rana, N.P., and Janssen, M., Lal, B., Williams, M.D., and Clement, M. (2017b). An Empirical Validation of a Unified Model of Electronic Government Adoption (UMEGA). Government Information Quarterly, DOI: 10.1016/j.giq.2017 .03.001.

Dwivedi, Y.K., Rana, N.P., Jeyaraj, A., Clement, M., and Williams, M.D. (2017a). Reexamining the Unified Theory of Acceptance and Use of Technology (UTAUT): Towards a Revised Theoretical Model. Information Systems Frontiers, DOI: 10.1007/s10796-017-9774-y.

Eriksson, K. and Nilsson. D. (2007). Determinants of the continued use of self-service technology: The case of Internet banking. Technovation. 27(4), 159-167.

Eriksson, K., Kerem, K. and Nilsson, D. (2005). Customer acceptance of internet banking in Estonia. International Journal of Bank Marketing, 23(2), 200-216.

Eriksson, K., Kerem, K., and Nilsson, D. (2008). The adoption of commercial innovations in the former Central and Eastern European markets. The case of internet banking in Estonia. International Journal of Bank Marketing, 26(3), 154-169.

Faqir, R. S. (2013). Cybercrimes in Jordan: A legal assessment on the effectiveness of information system crimes Law No (30) of 2010. International Journal of Cyber Criminology, 7(1), 81-90.

Featherman, M. S. and Pavlou, P. A. (2003). Predicting e-services adoption: A perceived risk facets perspective. International Journal of Human-Computer Studies, 59(4), 451474.

Fishbein, M. and Ajzen, I. (1975). Belief, attitude, intention and behavior: An introduction to theory and research. Reading, Massachusetts: Addison Wesley.

Flavián, C., Guinaliu, M. and Torres, E. (2006). How bricks-and-mortar attributes affect online banking adoption. International Journal of Bank Marketing, 24(6), 406-423.

Fornell, C. and Larcker, D. F. (1981). Evaluating structural equation models with unobservable variables and measurement error. Journal of Marketing Research, 18(1), 39-50.

Gan, C., Clemes, M., Limsombunchai, V., and Weng, A. (2006). A logit analysis of electronic banking in New Zealand. International Journal of Bank Marketing, 24(6), 360-383.

Gefen, D., Karahanna, E. and Straub, D. W. (2003). Trust and TAM in online shopping: An integrated model. MIS Quarterly, 27(1), 51-90.

Gerrard, P. and Cunningham, J. B. (2003). Diffusion of Internet banking among Singapore consumers. International of Bank Marketing, 21(1), 16-29.

Gumussoy, C. A. (2016). Usability guideline for banking software design. Computers in Human Behavior, 62, 277-285.

Hair Jr., J. F., Black, W. C., Babin, B. J. and Anderson, R. E. (2010). Multivariate data analysis: A global perspective. (7 $7^{\text {th }}$ ed.). Pearson Education International.

Hall, S. D., Ray, W. E., and Knight, L. E. (1999). Using Internet for retail access: Banks found lagging. Journal of Retail Banking Services, 21, 51-55.

Ho, S. and Ko, Y. (2008). Effect of self-service technology on customer value and customer readiness: The case study of Internet banking. Internet Research, 18(4), 427-446.

Hwang, Y. and Kim, D. J. (2007). Customer self-service systems: The effects of perceived web quality with service contents on enjoyment, anxiety, and e-trust. Decision Support Systems, 43(3), 746-760. 
Irani, Z., Dwivedi, Y. K., and Williams, M. D. (2009). Understanding consumer adoption of broadband: An extension of the technology acceptance model. Journal of the Operational Research Society, 60(10), 1322-1334.

Jaruwachirathanakul, B. and Fink, D. (2005). Internet banking adoption strategies for a developing country: The case of Thailand. Internet Research, 15(3), 295-311.

Kesharwani, A. and Bisht, S. S. (2012). The impact of trust and perceived risk on Internet banking adoption in India: An extension of technology acceptance model. International Journal of Bank Marketing, 30(4), 303-322.

Khraim, H. S., Shoubaki, Y. E., and Khraim, A. S. (2011). Factors affecting Jordanian consumers' adoption of mobile banking services. International Journal of Business and Social Science, 2(20), 96-105.

Kim, G., Shin, B. and Lee, H. G. (2009). Understanding dynamics between initial trust and usage intentions of mobile banking. Information Systems Journal, 19(3), 283-311.

Kim, K. K. and Prabhakar, B. (2004). Initial trust and the adoption of B2C e-commerce: The case of internet banking. ACM Sigmis Database, 35(2), 50-64.

Kim, M. J., Chung, N., and Lee, C. K. (2011). The effect of perceived trust on electronic commerce: Shopping online for tourism products and services in South Korea. Tourism Management, 32(2), 256-265.

Kolodinsky, J. M., Hogarth, J. M. and Hilgert, M. A. (2004). The adoption of electronic banking technologies by US consumers. The International Journal of Bank Marketing, 22(4), 238-259.

Kuisma, T., Laukkanen, T., and Hiltunen, M. (2007). Mapping the reasons for resistance to Internet banking: A means-end approach. International Journal of Information Management, 27(2), 75-85.

Laukkanen, P., Sinkkonen, S. and Laukkanen, T. (2008). Consumer resistance to internet banking: Postponers, opponents and rejectors. The International Journal of Bank Marketing, 26(6), 440-455.

Laukkanen, T., Sinkkonen, S., and Laukkanen, P. (2009). Communication strategies to overcome functional and psychological resistance to Internet banking. International Journal of Information Management, 29(2), 111-118.

Laukkanen, T., Sinkkonen, S., Kivijärvi, M., and Laukkanen, P. (2007). Innovation resistance among mature consumers. The Journal of Consumer Marketing, 24(7), 419-427.

Lee, J. and Allaway, A. (2002). A key to marketing financial services: The right mix of products, services, channels and customers. Journal of Services Marketing, 16(3), 238-258.

Lee, Y. H., Hsieh, Y. C., and Hsu, C. N. (2011). Adding innovation diffusion theory to the technology acceptance model: Supporting employees' intentions to use e-learning systems. Educational Technology \& Society, 14(4), 124-137.

Liao, S., Shao, Y., Wang, H. and Chen, A. (1999). The adoption of virtual banking: An empirical study. International Journal of Information Management, 19(1), 63-74.

Limayem, M., Hirt, S. G., and Cheung, C. M. K. (2007). How habit limits the predictive power of intentions: The case of IS continuance. MIS Quarterly, 31(4), 705-737.

Limayem, M., Hirt, S. G., and Cheung, C. M. K. (2007). How habit limits the predictive power of intentions: The case of IS continuance. MIS Quarterly, 31(4), 705-737.

Malaquias, R. F., and Hwang, Y. (2016). An empirical study on trust in mobile banking: A developing country perspective. Computers in Human Behavior, 54, 453-461.

Malhotra, Y. and Galletta, D. F. (1999). Extending the technology acceptance model to account for social influence: Theoretical bases and empirical validation. In Proceedings of the 32nd Annual Hawaii International Conference on System Sciences HICSS-32, $5^{\text {th }}-8^{\text {th }}$ January 1999, Maui, HI, USA. IEEE. 
Mallat, N., Rossi, M., and Tuunainen, V. (2008). An empirical investigation of Mobile ticketing service adoption in public transportation. Pers Ubiquit Comput, 12(1), 5765.

Martins, G., Oliveira, T. and Popovic, A. (2014) Understanding the Internet banking adoption: A unified theory of acceptance and use of technology and perceived risk application. International Journal of Information Management, 34(1), 1-13.

Migdadi, Y. K. A. (2012). The developing economies' banks branches operational strategy in the era of e-banking: The case of Jordan. Journal of Emerging Technologies in Web Intelligence, 4(2), 189-197.

Moon, J. W. and Kim, Y. G. (2001). Extending the TAM for a World-Wide-Web context. Information \& Management, 38(4), 217-230.

Nunnally, J. C. (1978). Psychometric theory. New York, NY: McGraw-Hill.

Oliver, R. L., and Bearden, W. O. (1985). Crossover effects in the theory of reasoned action: A moderating influence attempt. Journal of Consumer Research, 12(3), 324-340.

Parasuraman, A. (2000). Technology Readiness Index (TRI): A multiple-item scale to measure readiness to embrace new technologies. Journal of Service Research, 2(4), 307-320.

Poon, W. C. (2008). Users' adoption of e-banking services: The Malaysian perspective. Journal of Business \& Industrial Marketing, 23(1), 59-69.

Rana, N.P., Dwivedi, Y.K., and Williams, M.D. (2015). A Meta-Analysis Application for Synthesizing Findings of Existing Research on Citizen Adoption of E-Government. Information Systems Frontiers, 17(3), 547-563.

Rana, N.P., Dwivedi, Y.K., Lal, B., Williams, M.D., and Clement, M. (2017). Citizens' Adoption of an Electronic Government System: Toward a Unified View. Information Systems Frontiers, 19(3), 549-568.

Rana, N.P., Dwivedi, Y.K., Williams, M.D., and Weerakkody, V. (2016). Adoption of Online Public Grievance Redressal System in India: Toward Developing a Unified View. Computers in Human Behavior, 59, 265-282.

Riffai, M. M. M. A., Grant, K. and Edgar, D. (2012). Big TAM in Oman: Exploring the promise of on-line banking, its adoption by customers and the challenges of banking in Oman. International Journal of Information Management, 32(3), 239-250.

Rodrigues, L. F., Oliveira, A., and Costa, C. J. (2016). Does ease-of-use contributes to the perception of enjoyment? A case of gamification in e-banking. Computers in Human Behavior, 61, 114-126.

Rogers, E. M. (2003). Diffusion of innovations ( $5^{\text {th }}$ Ed.). New York, NY: Free Press.

Sharma, S.K., Govindaluri, M.S., Al-Muharrmi, S. and Tarhini, A. (2017). A multi-analytical model for mobile banking adoption: A developing country perspective. Review of International Business and Strategy, 27(1)

Sheth, J. N. (1981). Psychology of innovation resistance: The less developed concept (LDC) in diffusion research. Research in Marketing, 4(3), 273-282.

Sheth, J. N., Newman, B. I., and Gross, B. L. (1991). Why we buy what we buy: A theory of consumption values. Journal of Business Research, 22(2), 159-170.

Shih, Y. and Fang, K. (2004). The use of a decomposed theory of planned behaviour to study internet banking in Taiwan. Internet Research, 14(3), 213-223.

Shih, Y. and Fang, K. (2006). Effects of network quality attributes on customer adoption intentions of internet banking. Total Quality Management, 17(1), 61-77.

Simintiras, A. C., Dwivedi, Y. K., and Rana, N. P. (2014). Can marketing strategies enhance the adoption of electronic government initiatives? International Journal of Electronic Government Research (IJEGR), 10(2), 1-7. 
Tam, C., and Oliveira, T. (2016). Understanding the impact of m-banking on individual performance: DeLone \& McLean and TTF perspective. Computers in Human Behavior, 61, 233-244.

Tarhini, A., El-Masri, M., Ali, M., and Serrano, A. (2016). Extending the UTAUT model to understand the customers' acceptance and use of internet banking in Lebanon: A structural equation modeling approach. Information Technology and People, 29 (4), 830-849

Taylor, S. and Todd, P. A. (1995). Decomposition and crossover effects in the theory of planned behavior: A study of consumer adoption intentions. International Journal of Research in Marketing, 12(2), 137-155.

The Gulf Today. (2012). Jordan's Internet users stand at 3.535 million: August 19, 2012. Available from: http://gulftoday.ae/portal/cf77a112-4874-4abe-bba8-4265dc1aa8c9. aspx. Accessed: 08.06.16.

The Jordan Times. (2013). Mobile phone penetration projected to reach 200\%. Available from: $\quad$ http://jordantimes.com/mobile-phone-penetration-projected-to-reach-200. Accessed: 25.07.16.

The Jordan Times. (2014). Cybercrime a growing threat to internet users in Jordan. Available from: http://jordantimes.com/cyber-crime-a-growing-threat-to-internet-users-injordan. Accessed: 16.08.16.

Van der Heijden, H. (2004). User acceptance of hedonic information systems. MIS Quarterly, 28(4), 695-704.

Venkatesh, V. (2000). Determinants of perceived ease of use: Integrating perceived behavioral control, computer anxiety and enjoyment into the technology acceptance model. Information Systems Research, 11(4), 342-365.

Venkatesh, V. and Davis, F. D. (2000). A theoretical extension of the technology acceptance model: Four longitudinal field studies. Management Science, 46(2), 186-204.

Venkatesh, V., Morris, M., Davis, G., and Davis, F. (2003). User acceptance of information technology: Toward a unified view. MIS Quarterly, 27(3), 425-478.

Venkatesh, V., Thong, J. Y. L. and Xu, X. (2012). Consumer acceptance and use of information technology: Extending the unified theory of acceptance and use of technology. MIS Quarterly, 36(1), 157-178.

Walker, R. and Johnson, L. (2006). Why consumers use and do not use technology-enabled services. Journal of Services Marketing, 20(2), 125-135.

Wan, G. H. and Che, P. (2004). Chinese air travelers' acceptance towards electronic ticketing. In Proceedings of Engineering Management Conference, (1, pp. 269-275), 18 ${ }^{\text {th }}-21^{\text {st }}$ October 2004. IEEE.

Wang, Y. S., Wang, Y. M., Lin, H. H. and Tang, T. I. (2003). Determinants of user acceptance of internet banking: An empirical study. International Journal of Service Industry Management, 14(5), 501-519.

Yoon, H. S., and Steege, L. M. B. (2013). Development of a quantitative model of the impact of customers' personality and perceptions on Internet banking use. Computers in Human Behavior, 29(3), 1133-1141.

Yousafzai, S. Y., Foxall, G. and Pallister, J. G. (2010). Explaining internet banking behavior: Theory of reasoned action, theory of planned behavior, or technology acceptance model. Journal of Applied Social Psychology, 40(5), 1172-1202.

Yousafzai, S. Y., Pallister, J. G., and Foxall, G. R. (2005). Strategies for building and communicating trust in electronic banking: A field experiment. Psychology and Marketing, 22(2), 181-201.

Zhou, T. (2012). Understanding users' initial trust in Mobile banking: An elaboration likelihood perspective. Computers in Human Behavior, 28(4), 1518-1525. 
Zhou, T., Lu, Y., and Wang, B. (2010). Integrating TTF and UTAUT to explain mobile banking user adoption. Computers in Human Behavior, 26(4), 760-767.

Zhu, Z., Nakata, C., Sivakumar, K., and Grewal, P. (2013). Fix it or leave it? Customer recovery from self-service technology failure. Journal of Retailing, 89(1), 15-29.

Appendix I: Measurement Items Adopted

\begin{tabular}{|c|c|c|c|}
\hline Constructs & Item & Measure & Source(s) \\
\hline \multirow{4}{*}{$\begin{array}{l}\text { Performance } \\
\text { Expectancy }\end{array}$} & PE1 & I find Internet banking useful in my daily life. & \multirow{4}{*}{ Venkatesh et al. (2012) } \\
\hline & PE2 & $\begin{array}{l}\text { Using Internet banking increases my chances of } \\
\text { achieving tasks that are important to me. }\end{array}$ & \\
\hline & PE3 & $\begin{array}{l}\text { Using Internet banking helps me accomplish } \\
\text { tasks more quickly. }\end{array}$ & \\
\hline & PE4 & $\begin{array}{llll}\text { Using Internet banking increases my } \\
\text { productivity. }\end{array}$ & \\
\hline \multirow{4}{*}{$\begin{array}{l}\text { Effort } \\
\text { Expectancy }\end{array}$} & EE1 & $\begin{array}{l}\text { Learning how to use Internet banking is easy for } \\
\text { me. }\end{array}$ & \multirow{4}{*}{ Venkatesh et al. (2012) } \\
\hline & EE2 & $\begin{array}{l}\text { My interaction with Internet banking is clear } \\
\text { and understandable. }\end{array}$ & \\
\hline & EE3 & I find Internet banking easy to use. & \\
\hline & EE4 & $\begin{array}{l}\text { It is easy for me to become skilful at using } \\
\text { Internet banking. }\end{array}$ & \\
\hline \multirow{3}{*}{ Social Influence } & SI1 & $\begin{array}{l}\text { People who are important to me think that I } \\
\text { should use Internet banking. }\end{array}$ & \multirow{3}{*}{ Venkatesh et al. (2012) } \\
\hline & SI2 & $\begin{array}{l}\text { People who influence my behaviour think that I } \\
\text { should use Internet banking. }\end{array}$ & \\
\hline & SI3 & $\begin{array}{l}\text { People whose opinions that I value prefer that I } \\
\text { use Internet banking. }\end{array}$ & \\
\hline \multirow{4}{*}{$\begin{array}{l}\text { Facilitating } \\
\text { Conditions }\end{array}$} & FC1 & $\begin{array}{l}\text { I have the resources necessary to use Internet } \\
\text { banking. }\end{array}$ & \multirow{4}{*}{ Venkatesh et al. (2012) } \\
\hline & FC2 & $\begin{array}{l}\text { I have the knowledge necessary to use Internet } \\
\text { banking. }\end{array}$ & \\
\hline & FC3 & $\begin{array}{l}\text { Internet banking is compatible with other } \\
\text { technologies I use. }\end{array}$ & \\
\hline & FC4 & $\begin{array}{l}\text { I can get help from others when I have } \\
\text { difficulties using Internet banking. }\end{array}$ & \\
\hline \multirow{3}{*}{$\begin{array}{l}\text { Hedonic } \\
\text { Motivation }\end{array}$} & HM1 & Using Internet banking is fun. & \multirow[t]{3}{*}{ Venkatesh et al. (2012) } \\
\hline & HM2 & Using Internet banking is enjoyable. & \\
\hline & HM3 & Using Internet banking is entertaining. & \\
\hline \multirow[b]{3}{*}{ Price Value } & PV1 & Internet banking is reasonably priced. & \multirow{3}{*}{ Venkatesh et al. (2012) } \\
\hline & PV2 & Internet banking is good value for the money. & \\
\hline & PV3 & $\begin{array}{l}\text { At the current price, Internet banking provides } \\
\text { good value. }\end{array}$ & \\
\hline \multirow{4}{*}{ Habit } & HT1 & $\begin{array}{l}\text { The use of Internet banking has become a habit } \\
\text { for me. }\end{array}$ & \multirow{4}{*}{ Venkatesh et al. (2012) } \\
\hline & HT2 & I am addicted to using Internet banking. & \\
\hline & HT3 & I must use Internet banking. & \\
\hline & HT4 & $\begin{array}{l}\text { Using Internet banking has become natural to } \\
\text { me }\end{array}$ & \\
\hline \multirow{5}{*}{$\begin{array}{l}\text { Behavioural } \\
\text { Intention }\end{array}$} & BI1 & I intend to use Internet banking in the future. & \multirow{4}{*}{ Venkatesh et al. (2012) } \\
\hline & $\mathrm{BI} 2$ & $\begin{array}{l}\text { I will always try to use Internet banking in my } \\
\text { daily life. }\end{array}$ & \\
\hline & $\mathrm{BI} 3$ & I plan to use Internet banking in future. & \\
\hline & $\mathrm{BI} 4$ & $\begin{array}{l}\text { I predict I would use Internet banking in the } \\
\text { future. }\end{array}$ & \\
\hline & PR1 & $\begin{array}{l}\text { Using Internet banking services subjects my } \\
\text { banking account to potential fraud. }\end{array}$ & $\begin{array}{l}\text { Featherman and Pavlou } \\
\text { (2003) }\end{array}$ \\
\hline
\end{tabular}




\begin{tabular}{|c|c|c|c|}
\hline \multirow[t]{6}{*}{ Perceived Risk } & PR2 & $\begin{array}{l}\text { Using Internet banking services subjects my } \\
\text { banking account to financial risk. }\end{array}$ & \\
\hline & PR3 & $\begin{array}{l}\text { I think using Internet banking puts my privacy } \\
\text { at risk. }\end{array}$ & \\
\hline & PR4 & $\begin{array}{l}\text { Hackers might take control of my bank account } \\
\text { if I use Internet banking. }\end{array}$ & \\
\hline & PR5 & $\begin{array}{l}\text { Using Internet banking will not fit well with my } \\
\text { self-image. }\end{array}$ & \\
\hline & PR6 & $\begin{array}{l}\text { Internet banking might not perform well and } \\
\text { will create problems with my bank account. }\end{array}$ & \\
\hline & PR7 & $\begin{array}{l}\text { Using Internet banking exposes me to an overall } \\
\text { risk. }\end{array}$ & \\
\hline \multirow{5}{*}{ Adoption } & SR 1 & $\begin{array}{l}\begin{array}{l}\text { Balance enquiries and downloaded bank } \\
\text { statements }\end{array} \\
\end{array}$ & \multirow{5}{*}{$\begin{array}{l}\text { Curran and Meuter } \\
(2005 / 2007) \text {, Martins et al. } \\
(2014)\end{array}$} \\
\hline & SR 2 & Funds transfer & \\
\hline & SR 3 & Requesting cheque book or bank certificates & \\
\hline & SR 4 & Paying bills & \\
\hline & SR 5 & $\begin{array}{l}\text { Request increase in credit card(s) limit or pay } \\
\text { any balance due }\end{array}$ & \\
\hline
\end{tabular}

